\title{
A Sustainability Index within Water and Wastewater Management in Sweden: An Evaluation of Eight Case Studies
}

\author{
Nasik Najar ${ }^{1, *(\mathbb{C})}$ and Kenneth M. Persson ${ }^{2}$ \\ 1 Department of Construction Engineering and Lighting Science, School of Engineering, Jönköping University, \\ 55111 Jönköping, Sweden \\ 2 Division of Water Resources Engineering, Lund University, P.O. Box 118, S-221 00 Lund, Sweden; \\ kenneth_m.persson@tvrl.lth.se \\ * Correspondence: nasik.najar@ju.se; Tel.: +46-736-556-581
}

check for updates

Citation: Najar, N.; Persson, K.M. A Sustainability Index within Water and Wastewater Management in Sweden: An Evaluation of Eight Case Studies. Water 2021, 13, 1879. https:// doi.org/10.3390/w13141879

Academic Editor: Akintunde O. Babatunde

Received: 4 June 2021

Accepted: 2 July 2021

Published: 7 July 2021

Publisher's Note: MDPI stays neutral with regard to jurisdictional claims in published maps and institutional affiliations.

Copyright: (c) 2021 by the authors. Licensee MDPI, Basel, Switzerland. This article is an open access article distributed under the terms and conditions of the Creative Commons Attribution (CC BY) license (https:// creativecommons.org/licenses/by/ $4.0 /)$.

\begin{abstract}
A sustainability index (SI) is a benchmark for guiding the activities of municipal water and wastewater (W and WS) utilities toward sustainability. The SI has been used in Sweden since 2014 as an internal benchmark management tool facilitating the strategic work of organizations. This study assesses how the SI was applied in practice by eight utilities (Orgs 1-8) from 2015 to 2019. The study was performed using in-depth semi-structured interviews with managers of the utilities and analyzing 32 SI reports and other documents. The utilities generally perform better in all parameters compared with the national average. Three utilities had improved results during the study period, while the other five had unchanged development. Five utilities use the SI index to improve their performance, and three use the SI results to grade the organization. All utilities are concerned with sustainability and wish to improve their performance. The study found that the parameter "Status of W and WS fixed facilities" was the furthest from sustainability. The study also clarifies that the technical committee has the primary responsibility to ensure that the technical office meets the sustainability objectives.
\end{abstract}

Keywords: sustainability index; parameters; ensure sustainability; reinvestment fund; fixed facilities; W and WS management in Sweden

\section{Introduction}

In the pursuit of the creation of a sustainable society, public water and wastewater systems (W and WS) are essential parts of the concept. W and WS technology involves complex tasks with multiple systems, and many different aspects must be considered [1]. The requirements for $\mathrm{W}$ and WS organizations are high. Uncertainty about climate change, even within a relatively short time until 2050, will mean further requirements to increase security levels against floods and other environmental and human impacts [2]. However, it is a big task to manage the systems to be used in the best possible way so they can withstand the challenges they will face.

Sweden's 290 municipalities should provide residents with a water supply and manage their wastewater in a long-term sustainable way, considering the environment and human health. Thus, these municipalities are responsible for the building, renewal, and expansion of general W and WS facilities, and they decide where such services need to be arranged. Today, for 90\% of Sweden's population, drinking water is delivered and wastewater is treated through municipal W and WS services [3].

The Local Government Act (SFS 2018:1350) gives municipal organizations the freedom to plan W and WS operations. This freedom has led to differences in how far W and WS organizations have come in ensuring sustainable water activities.

Based on the available experience, the W and WS network is in poor condition and needs renovation, due to age and other factors [4]. These factors can be identified by having well-functioning information systems through which operational disruptions, complaints, 
and additional information can be gathered by continuous monitoring. Then, opportunities can be created to statistically judge when efforts should be made to work on the network [4].

The lack of maintenance causes leaking water and wastewater pipes, affecting the economy, the environment, and future generations. However, it has not yet resulted in any critical health risks or other significant problems. Residents are generally satisfied, as they get good-quality water when they turn on the tap and notice that their wastewater easily disappears down the drain [5].

To ensure quality, to meet present and future needs, and to carry out W and WS services, some tools have been developed and applied by municipalities. Since 2014, the Swedish Water and Wastewater Association (SWWA) has collaborated with its members, water utilities of the municipalities, to develop a sustainability index (SI) tool. The SI is aimed at helping municipal W and WS organizations analyze and develop the sustainability of their operations in the short and long term. The SWWA also uses the SI to identify challenges that its members face [6].

The SI tool is a part of a continuous improvement effort and an essential key for guiding municipal $\mathrm{W}$ and WS activities toward sustainability [7].

The starting point for developing the SI was to identify the functional requirements set on the W and WS system, explanatory factors, and key figures that are important for the efficiency of operation [8]. The use of key figures is a way to evaluate the direction in which the activities are going in order to steer them correctly [9]. Each important key is presented in a performance grade numbered from 0 to 2 and given a traffic-light color of green (good), yellow (needs improvement), or red (must be improved).

Utilities feed in their results to a web-based database annually. The number of participating utilities has increased every year, starting from 97 in 2014, and reaching 171 in 2019 and 184 in 2020. A consistent trend of the results from 2019, as in previous years, is that the daily operation functions well but there are no resources for long-term planning, which is assigned the color red as a sign of the shortcomings in the strategies used and indicates a need for measurement [7]. In broad terms, the results of the SI since its inception in 2014 show that national performance improvement is weaker than had been hoped [7].

This study provides an overview of how W and WS management is carried out in Sweden and aims specifically to evaluate the application of the SI tool through eight case studies, in order to (1) clarify the strategies used to eliminate the shortcomings defined by the SI, (2) clarify who is responsible for ensuring sustainability within the W and WS sector, and (3) identify the principles and methods of financing and evaluate whether they are sufficient to meet the sustainability requirements.

The following research questions guide the study: (1) How are the SI results for organizations 1-8 compared with each other and with national results? (2) What strategies do the organizations use to eliminate the shortcomings identified by the SI? (3) Who is primarily responsible for making the W and WS business sustainable? (4) What are the principles and methods of financing the sector and managing its fixed assets? (5) How do the W and WS organizations experience legislation regarding financing of the sector?

\section{Materials and Methods}

Eight municipal W and WS organizations that participated in the SI survey during 2014-2019 were chosen as case studies to be investigated and analyzed in detail. The size, geographical location of the municipalities, and the proportion of participation in SI of the category to which they belong were the motives for choosing the eight organizations. However, municipalities of all sizes have participated in the SI survey, but the proportion is more for larger municipalities. Out of 290 municipalities, 167 are small and have fewer than 20,000 inhabitants. Of these, the participation in SI was $43 \%$. There are 48 municipalities with a population from 50,000 to greater than 100,000 in Sweden, of which 45 , i.e., $94 \%$ of them, participated in SI [7]. For this study, we selected seven out of eight organizations from this range. Thus, this choice enabled the comparison between their results and the national results. The eighth case study was chosen from the third size category with 20,000-50,000 
inhabitants, which is a group of municipalities where the participation in SI is 72\% [7] to also highlight the performance within the organizations in this size. All organizations were selected in southern Sweden with similar geography and hydrologic regime but also to study any strategy of collaboration between them. According to SWWA, creating strong $\mathrm{W}$ and WS organizations is crucial in the long term. This means that municipalities and companies need to develop cooperation with others [3]. Figure 1 shows the methodological structure of this study. It shows the background material used in the study as secondary data and the case studies used as primary data.

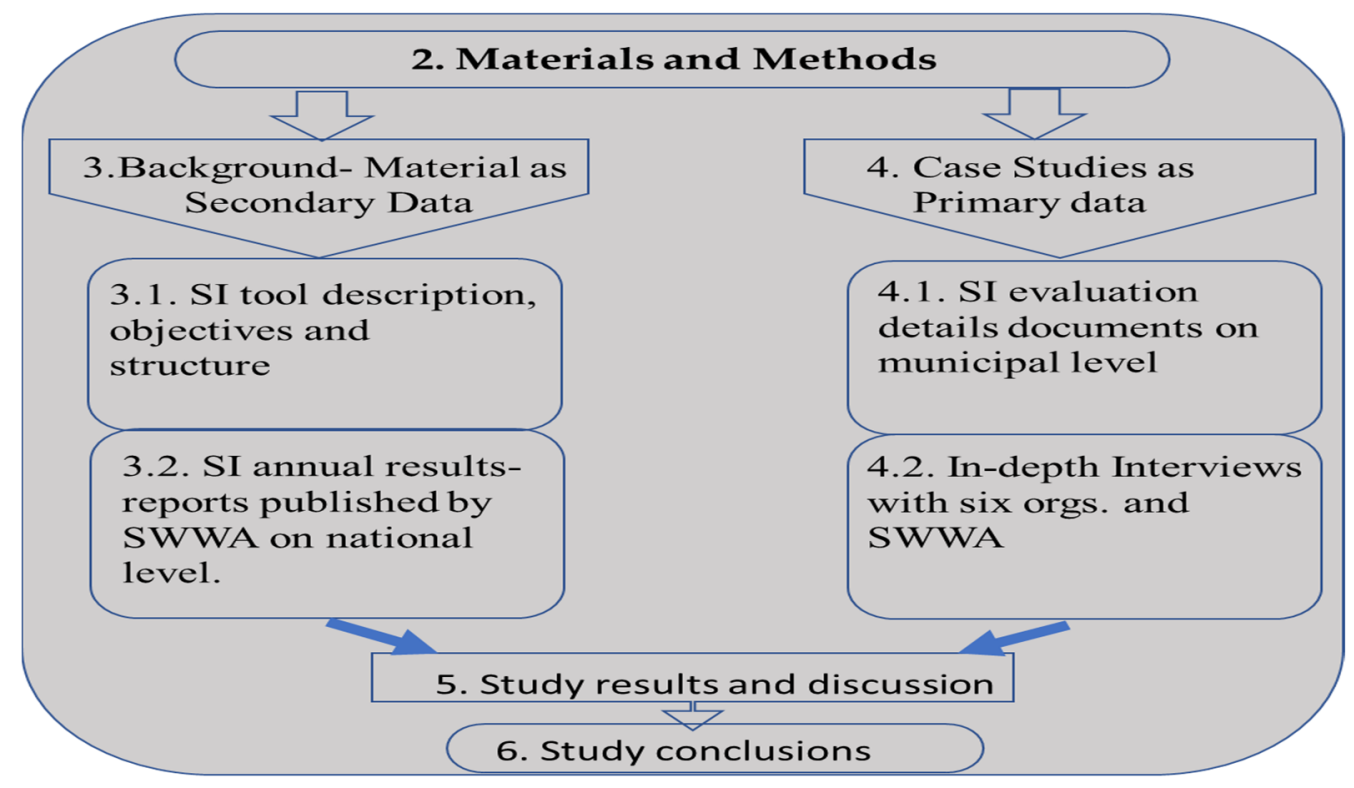

Figure 1. Methodological structure of the study.

The background material includes a description and structure of the SI. The annual SI result reports at the national level were reviewed, and results were compiled to compare the results for the eight studied organizations with the national results for all participating municipal utilities in the SI survey. The case studies included an analysis of the SI evaluation details documents at the municipal level for 2015, 2017, 2018, and 2019 and in-depth interviews with the managers. The description, review, and analysis of the background material are presented in Section 3, and the case studies are presented in Section 4.

\section{Background Material as Secondary Data}

3.1. SI Tool

\subsubsection{General Description and SI Objectives}

The SI was developed by SWWA 2014 and was implemented by municipal W and WS organizations through a survey in the SWWA Statistical System (VASS) database. The utilities can follow up on and evaluate virtually all their activities in the database. There are many essential strategic needs of municipal W and WS organizations, including discussions between business leaders and policymakers, tax adjustments, improvement work, longterm sustainability, preparation of strategic documents, analysis of the organizations, etc. The SI tool was designed to contribute to supporting these strategic needs and give the municipal W and WS organizations a way to analyze and improve their operations [8].

There are 290 municipalities in Sweden of different sizes based on the number of residents. The number of participating municipal W and WS organizations using the SI has increased steadily every year, from 97 in 2014 to 171 in 2019 [7]. 


\subsubsection{Structure of SI Tool}

The SI is based on 3 sustainability pillars, 14 parameters that capture sustainability, and 82 questions that interpret the parameters in more detail. The three base pillars are "Sustainable services for users", "Environmental sustainability", and "Sustainable resources". They account for the ecological, economic, and social aspects that define the Brundtland Commission's definition of sustainability [10].

The 3 base pillars, 14 parameters, and the codes of the 82 questions are presented in Figure 2. For example, the base pillar "sustainable service for users" consists of seven parameters and 31 questions of group code (T). These questions are divided between the seven parameters. Th1, Th2, and Th3 are the code of the three questions for the first parameter, "Healthy and safe water". The codes are compiled in numerical order for each pillar and associated parameters. The base pillars are shown in three colors: orange, brown, and light pink. The same colors were given to the related parameters, and the groups of questions were compiled in the same way as in the SI.

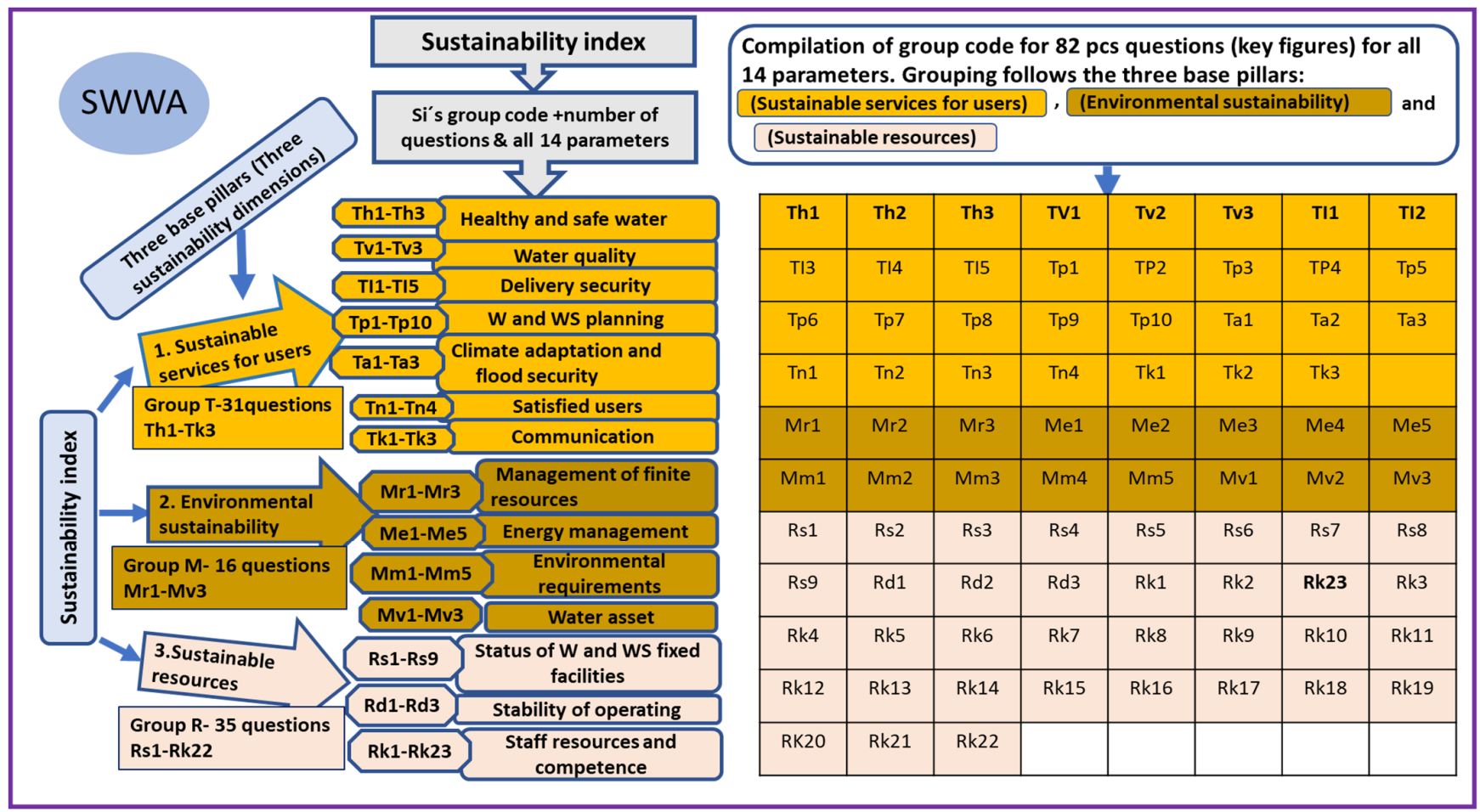

Figure 2. Three base pillars, fourteen parameters, and group code compilation for questions (key figures) of each base pillar and its parameters.

A translation of the questions is presented in Appendix A. They are gathered under the associated base pillars and the included parameters. When selecting the questions, SWWA included existing values, guidelines, and requirements from the trade and authorities. Thus, the SI reflects the ambitions and requirements of the W and WS branch. Appendix A shows the three base pillars with the included parameters and related questions. Figure A1 in Appendix A illustrates the seven parameters and 31 questions that belong to the base pillar "Sustainable services for users." Figure A2 in Appendix A shows the four parameters and 16 questions that belong to the base pillar "Environmental sustainability." Figure A3 in Appendix A shows the three parameters and 35 questions that belong to the base pillar "Sustainable resources." The utilities make a self-estimation of their performance and feed the answers to SWWA annually. 


\subsection{National SI Annual Result Reports}

Every year, SWWA compiles the SI survey results for the participating organizations based on the parameters at the national level. Figure 3 shows the results for 171 participating municipalities in the SI in 2019. It reflects that the W and WS sector lacks resources for long-term planning, which gives the red results. The biggest challenge lies in maintaining and improving the status of fixed facilities. This parameter has $78 \%$ red results as a sign of the shortcomings in the strategies used and indicates a need for measurement [7]. The SI results reports for 2015 and 2017-2019 show that W and WS organizations have had good functional operative ability to provide water services, such as drinking water supply and wastewater treatment. They have met environmental requirements, the delivery capacity is good, and customer satisfaction is high. However, the overall result has hardly improved, as can be seen from Figures 3 and 4. Figure 3 shows the results for 171 participating municipalities in the SI in 2019, and Figure 4 shows the total outcome for 2016-2019, i.e., the proportion of green/yellow/red parameters for all participating municipalities at the national level [7].

\begin{tabular}{|c|c|}
\hline $\begin{array}{l}\text { Base } \\
\text { pillars }\end{array}$ & Parameters \\
\hline \multirow{7}{*}{ 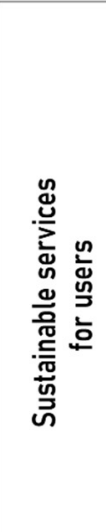 } & Healthy \& safe water \\
\hline & Water quality \\
\hline & Delivery security \\
\hline & W and WS planning \\
\hline & $\begin{array}{l}\text { Climate adaptation and } \\
\text { flood security }\end{array}$ \\
\hline & Satisfied users \\
\hline & Communication \\
\hline \multirow{4}{*}{ 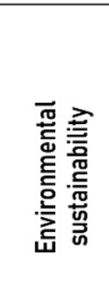 } & $\begin{array}{l}\text { Management with finite } \\
\text { resources }\end{array}$ \\
\hline & Energy management \\
\hline & $\begin{array}{l}\text { Environmental } \\
\text { requirements }\end{array}$ \\
\hline & Water asset \\
\hline \multirow{3}{*}{ 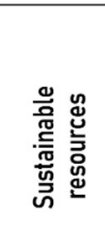 } & $\begin{array}{l}\text { The status of } W \text { and WS } \\
\text { fixed facilities }\end{array}$ \\
\hline & Stability of operating \\
\hline & $\begin{array}{l}\text { Staff resources \& } \\
\text { competence }\end{array}$ \\
\hline
\end{tabular}

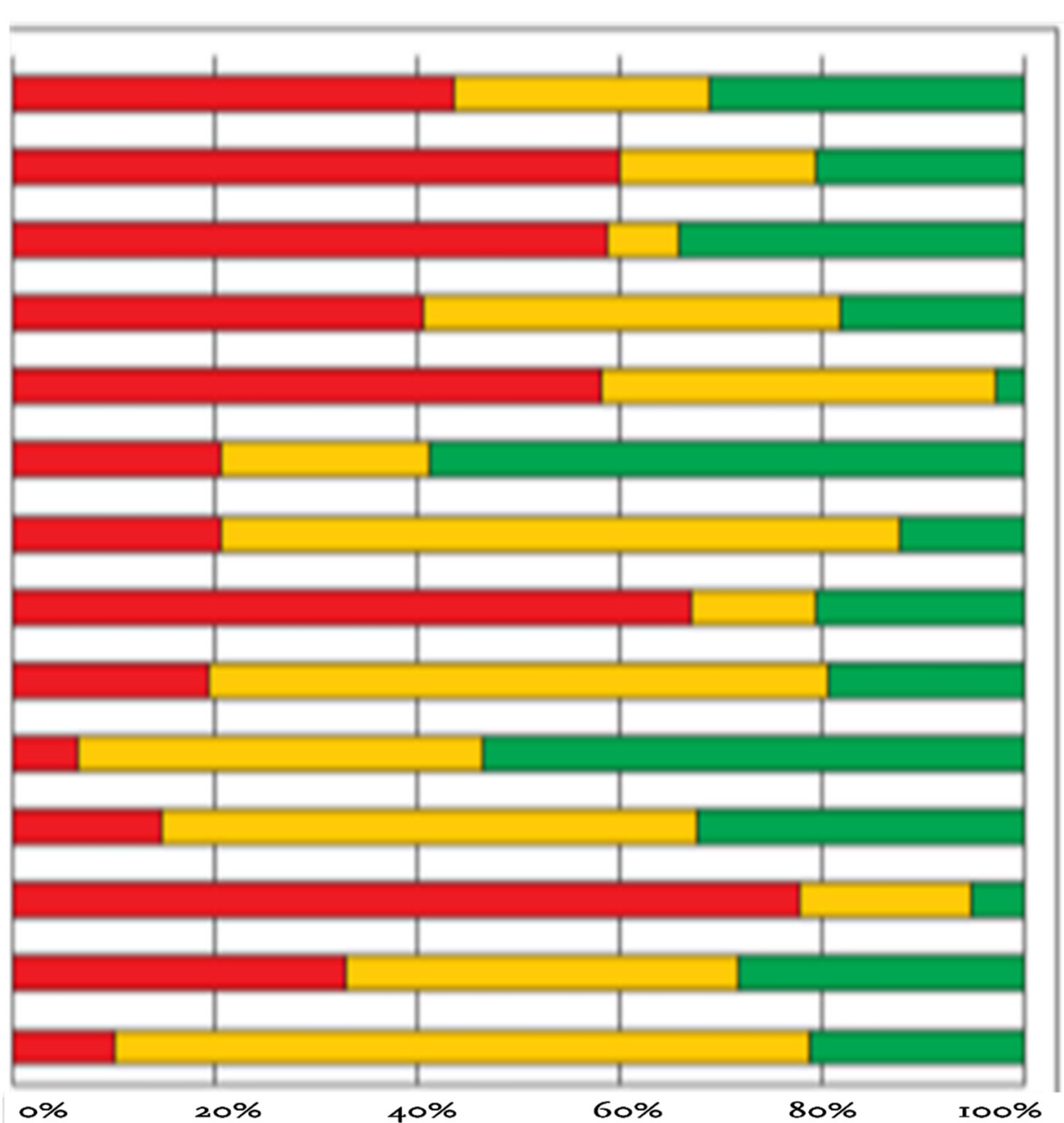

Figure 3. Parameter results for 171 participating municipalities in SI 2019 [7]. 


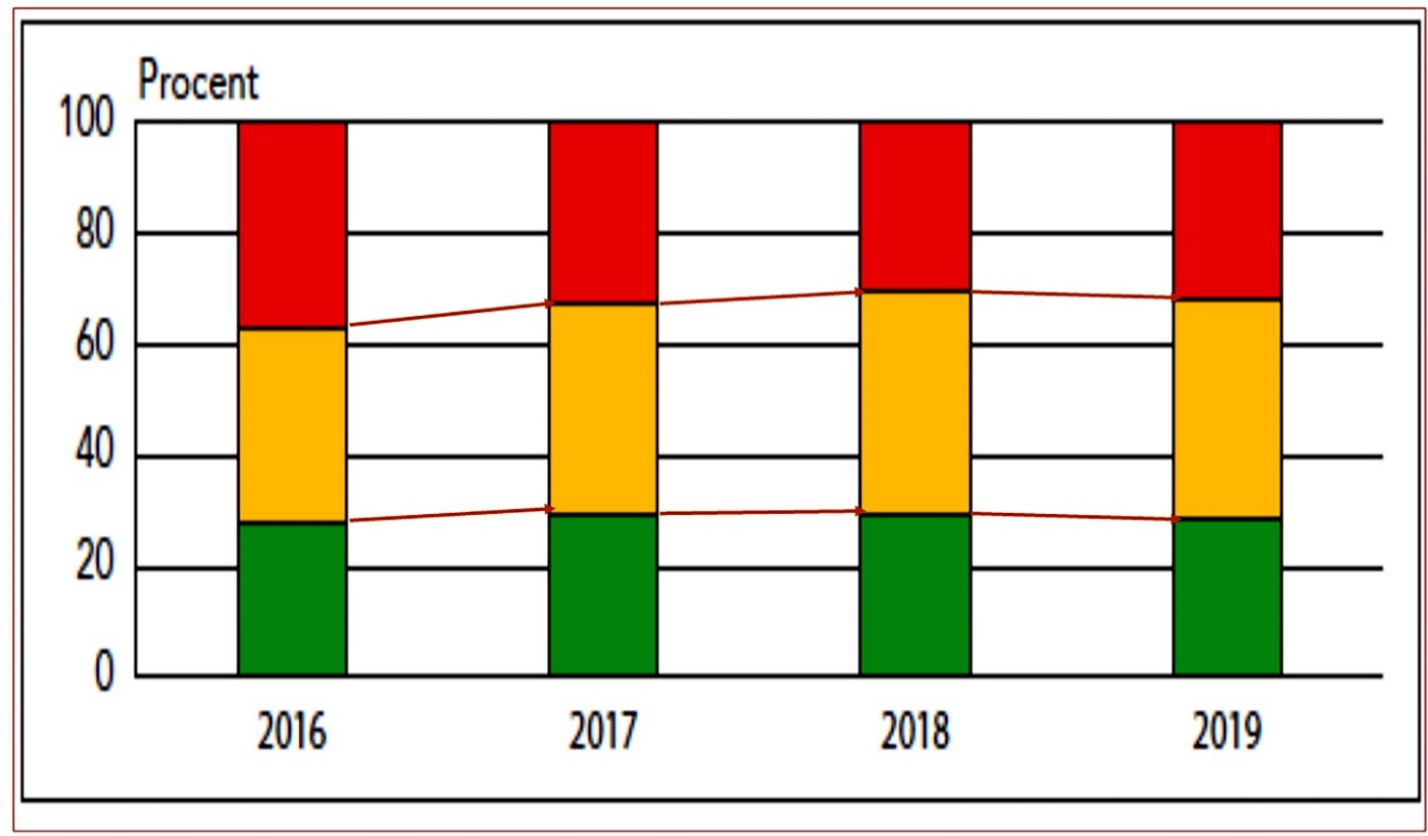

Figure 4. Summarized results for all participating municipalities in sustainability index 2016-2019 [7].

A slight improvement in 2019 can be noted at the national level compared with the results for 2016-2018, yet some deterioration can also be seen [7]; several municipalities expressed that they make stricter assessments when answering SI questions as they have become more familiar with the tool over the years. Being stricter affects the results in general and may partly explain why only minor improvements have been made. When the organizations start scrutinizing their performance, their awareness of how it actually looks increases.

According to an analysis of the results report for 2018, municipalities that participated in many SI surveys had improved results, but new participating organizations had worse outcomes. Therefore, the overall results are unchanged. However, the results analysis for 2019 (Figure 5) shows that the 109 municipalities that participated every year from 2016-2019 also had minimal changes.

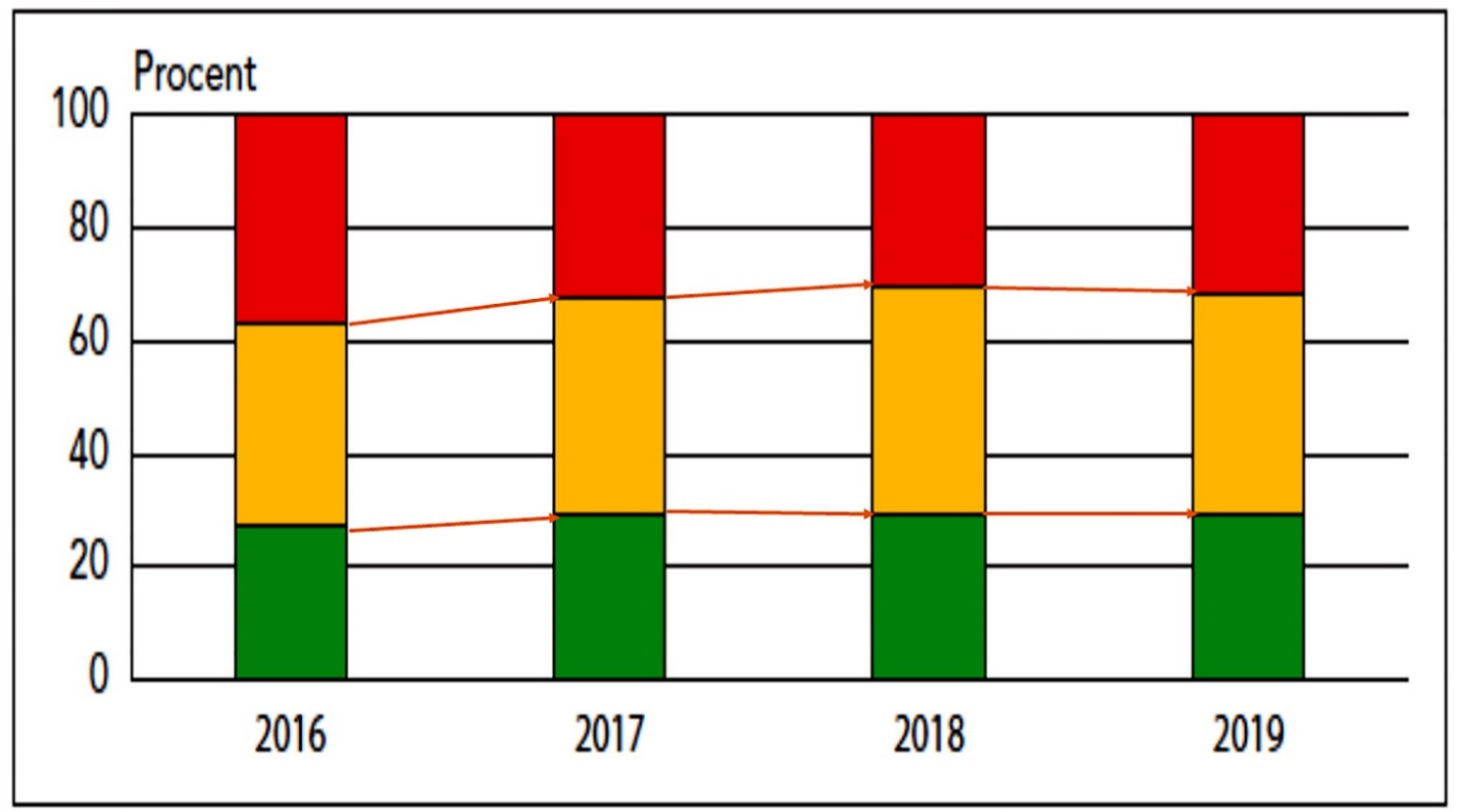

Figure 5. Summarized results in SI for 109 municipalities that participated in all surveys 2016-2019 [7]. 
The SI survey results also show that municipalities with more than 50,000 inhabitants had improved results, especially with a smaller proportion of parameters assessed as red than municipalities with fewer than 20,000. In summary, the improvement of national results is weaker than had been hoped, and the organization's size and capacity are important factors [7].

\section{Case Studies}

The municipalities in Sweden differ in size, geographic residence, political conditions, population development, average population, age, etc. [11]. The eight chosen municipalities for this study are located in southern Sweden, in six counties (Kronoberg, Västra Götaland, Östergötland, Jönköping, Blekinge, and Halland) (Figure 6). The organizations' names and locations are not given, and the study results are presented anonymously by their request. They are labeled Org 1 to Org 8 .

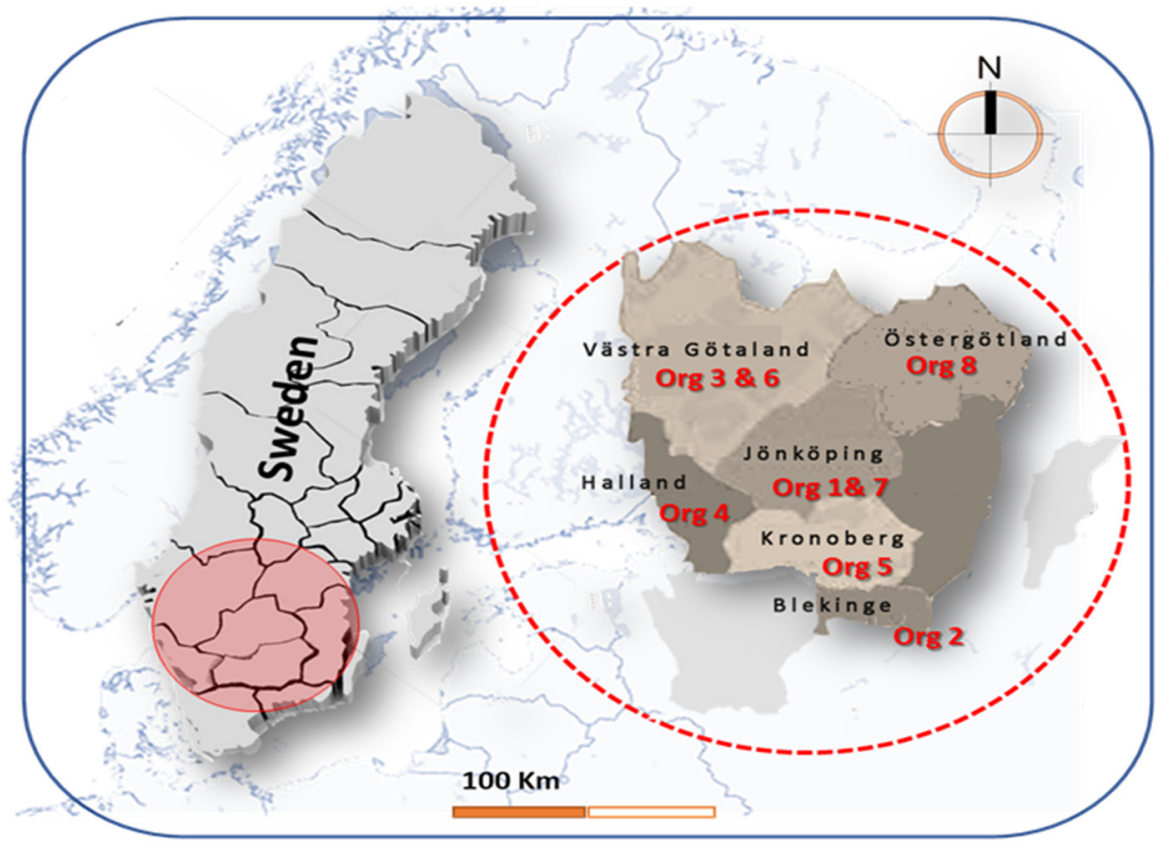

Figure 6. Map of Sweden and the studied organizations (Orgs 1-8) within the six counties.

Seven of the selected municipalities are among the 50 largest municipalities in Sweden, with a population in the range of 70,000-170,000 inhabitants. Since the participation of the municipal organizations of this category nationally is about $94 \%$, thus, they reflect the national result better than other sizes. The eighth has 30,000 to 35,000 inhabitants.

It was chosen to also highlight the performance within the organization in this size.

Each municipality has a city council (municipal parliament), with representatives directly elected by the residents every fourth year as the highest local decision level. It can organize the political control of the municipality in different ways; traditionally, it appoints a number of boards and committees with special responsibility for different tasks. A technical committee is commonly responsible for the technical office and employs a technical manager "further explained in Section 5.3.1". Orgs 1, 2, 3, 4, 5, and 7 have this traditional type of organization, which is the most common in Sweden [6]. Org 6 is organized as a municipal-owned company with a board of directors and a managing director. Org 8 is included in a public multi-utility company, which means that several of the technical activities in the municipality are run by the same company. Each activity constitutes its own business area in a multi-utility company [12]. The main source for supplying the raw water of five of the studied organizations is surface water. Org 2 takes its raw water from groundwater, and Orgs 4 and 5 take their raw water from groundwater supplemented with artificial infiltration from surface water. 


\subsection{SI Evaluation Details Documents of Eight Studied W and WS Organizations}

The SI evaluation details documents were obtained by SWWA after obtaining permission from the chosen municipalities. Each document contains 14 parameters and 82 questions for each organization and year. The codes of the questions, the questions themselves, and the parameters are stacked under the associated base pillars (Figure 7). Figure 7 illustrates a part of the SI evaluation details for Org 1 in 2019, showing questions Th1-Th3 for the parameter "Healthy and safe water" and the base pillar "Sustainable services for users".

\begin{tabular}{|c|c|c|c|}
\hline \multicolumn{4}{|c|}{$\begin{array}{l}\text { SI evaluation details } 2019 \text { Org1. } \\
\text { Sustainable services for users (base pillar) }\end{array}$} \\
\hline \multicolumn{2}{|c|}{$\begin{array}{l}\text { Parameters: Healthy \& Safe Water } \\
\text { Response rate: } 100 \%\end{array}$} & $\begin{array}{l}\text { Parameter value: red } \\
\text { Weighting limit }=2+1+0=3 / 3=1\end{array}$ & \\
\hline Code & Questions & Answer & Comments \\
\hline Th1 & $\begin{array}{l}\text { The proportion of routine tests (for self- } \\
\text { inspection) online and at works that are } \\
\text { unusable }\end{array}$ & $<1 \%$ & \\
\hline Th2 & $\begin{array}{l}\text { The proportion of unfit samples that are } \\
\text { investigated and due on analysis errors or } \\
\text { property errors }\end{array}$ & $\begin{array}{l}\text { All tests followed up and } \\
\text { investigated }\end{array}$ & $\begin{array}{l}\text { To be green on Th2, all } \\
\text { tests followed up, and } \\
100 \% \text { were due to analysis } \\
\text { errors or property errors }\end{array}$ \\
\hline Th3 & $\begin{array}{l}\text { Simplified or complete MBA (Microbiological } \\
\text { Barrier Analysis, formerly called GDP) } \\
\text { performed for all waterworks (max. } 5 \text { years old } \\
\text { if no changes have taken place). Note that } \\
\text { simplified MBA is enough but must have been } \\
\text { done for each waterworks (regardless of size) } \\
\text { to turn green. }\end{array}$ & No & $\begin{array}{l}\text { To be green on Th3, the } \\
\text { answer should be: Yes, and } \\
\text { sufficient barrier effect } \\
\text { achieved }\end{array}$ \\
\hline
\end{tabular}

Figure 7. Part of SI evaluation details for Org 1 in 2019.

It shows that the valuation of this parameter is red. The requirement for the parameter to be approved (green) is that all users must have sufficient security regarding their drinking water. This means that all waterworks must have implemented sufficient microbial barriers in all treatment plants.

Thirty-two SI evaluation details documents for the eight studied organizations in 2015, 2017, 2018, and 2019 were reviewed and analyzed based on the parameters and questions to illustrate each organization's performance when applying the SI tool and to show how the results have developed over the years.

The statistical weighting method was used to evaluate the total outcomes. Green answers got a weighting limit of 2 , yellow got 1 , and red got 0 . The weighting limit for each parameter was determined by calculating the average weighting limits of all questions. As shown in Figure 7, the weighting limit is obtained by giving 2 for Th1+, 1 for Th2+, and 0 for Th 3 , which equals 3 , and the average is $3 / 3=1$. The size of the weighting limit indicates the status of the question. Thus, a low value indicates that several issues within the parameter should be tackled, and a high value indicates the opposite.

\subsection{SI Interviews}

Interview questions were arranged and categorized into three main areas based on the study's goals and research questions. Many of the questions included a brief background based on the studied documents and collected data. Figures 8-10 were also sent with the interview questionnaire. The figures show the achieved SI results, differences in development, and the modification trend for the eight studied organizations in 2015, 2017, 2018, and 2019. 
Explanations of how the weighting method was used and how the results came out were also included. The questionnaire was emailed to the managers two weeks before the first interview to inform them and help them prepare for the interview. The interviews with the managers of Orgs 1, 3, 4, 5, 7, and 8 were conducted in September 2020. The managers of Org 2 and Org 6 had obstacles to participating. The interviews were conducted digitally over Zoom and recorded. Transcripts and summaries of the interview results were emailed to the interviewees to recheck the content. The research questions guided the interview questionnaire. The first question was answered by document analysis. The other four questions and related sub questions were answered by the managers via the interviews.
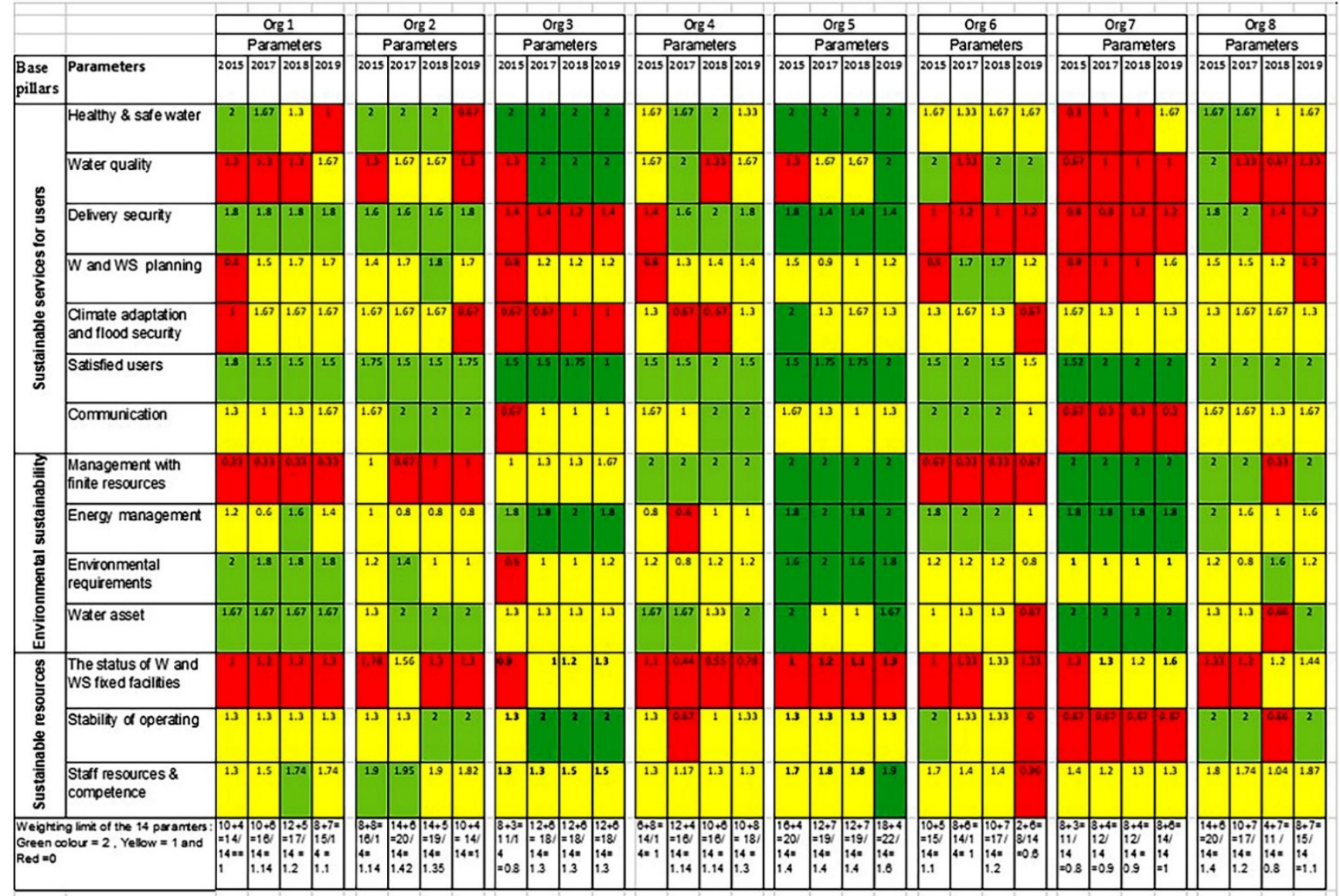

Figure 8. Compilation of results of SI parameters for Orgs 1-8 during 2015, 2017, 2018, and 2019.
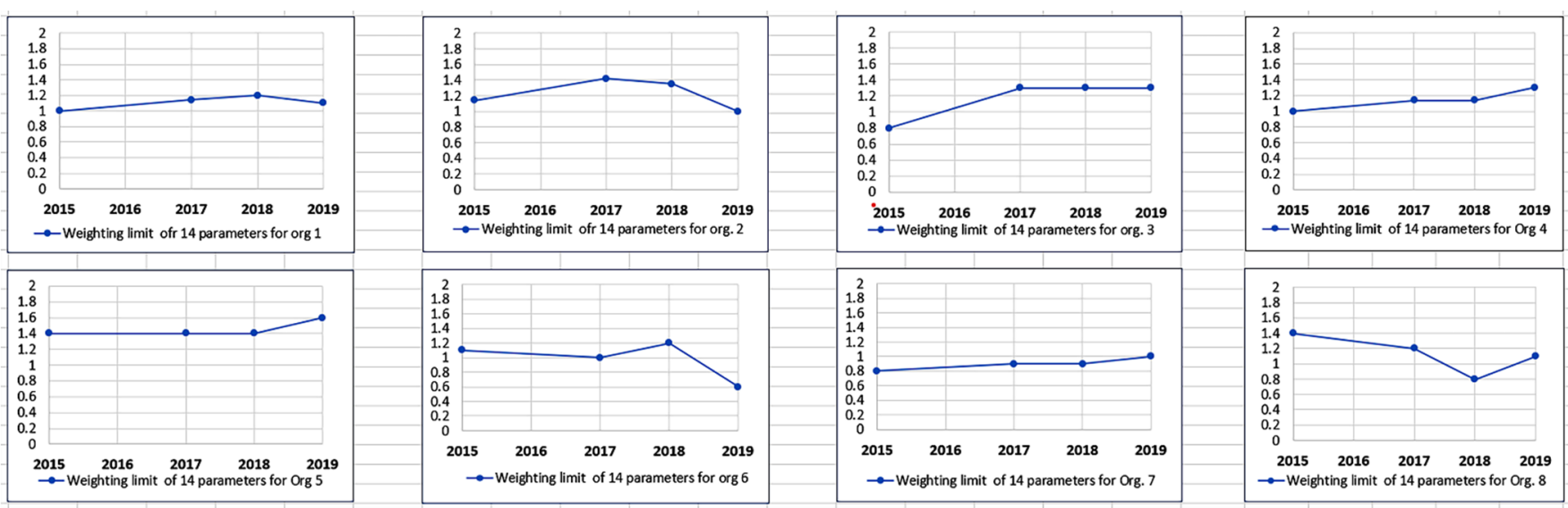

Figure 9. Development of SI results for 14 parameters for Orgs 1-8 in 2015-2017, 2018, and 2019. 


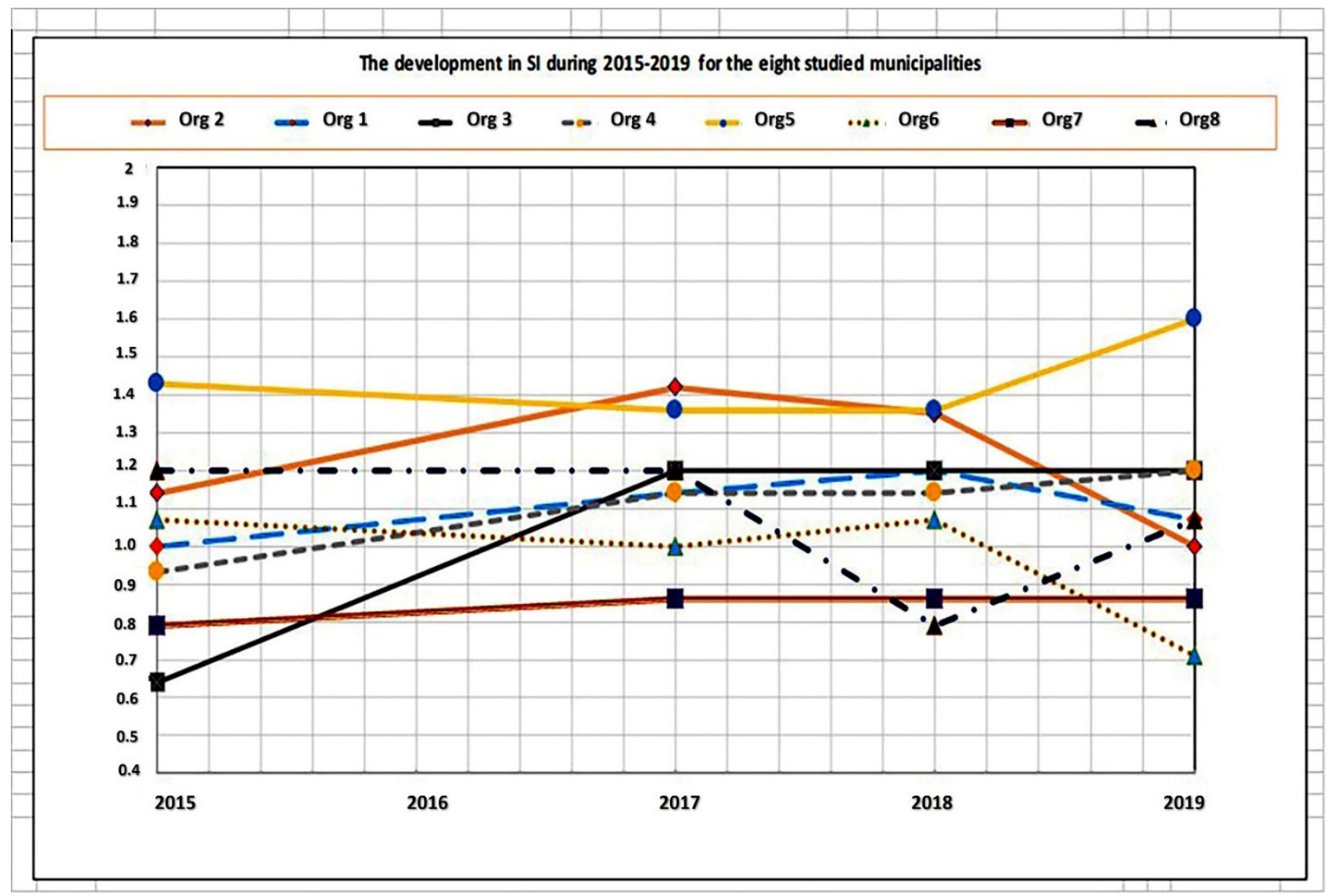

Figure 10. Alteration trend for SI parameters during 2015 and 2017-2019 for Orgs. 1-8.

\section{Results and Discussion}

\subsection{SI Results and Alteration Trend for Orgs 1-8}

The valuation of the 14 parameters for the eight surveyed organizations for 2015, 2017, 2018, and 2019 is shown in Figure 8, which also shows the weighting limits in all boxes for all parameters and the organizations. The numbers displayed in boxes in each row are the weighting limits for the parameter on the left of the row for the organizations and years. They were obtained by weighting all questions belonging to that parameter and taken from the SI evaluation documents (Figure 7). Similarly, the parameters in the bottom box of each column were weighted.

The last row of Figure 8 shows the weighting limits of the 14 parameters for each organization and the four surveyed years. These weighting limits, i.e., the development of SI results for all parameters and organizations in 2015-2017, 2018, and 2019 are also presented in Figure 9.

The graphs in Figure 9 reflect generally low, unchanged, or deteriorated development of the organizations' results toward sustainability during 2017, 2018, and 2019, except for Org 5.

Figures 8 and 9 show the differences in achieved performance between Orgs 1-8 and their starting point in 2014. Figure 10 shows the alteration trend for SI parameters during 2015 and 2017-2019 for the eight organizations.

It can be seen in Figures 9 and 10 that Orgs 4, 5, and 7 had an improved results trend during 2017-2019 to varying degrees. The change in results for Org 5 was the largest among the eight organizations, and the trend points upward during 2015-2019. Org 7 also had improved results during 2015-2019, and the trend is positive; it started from a low level in 2015. Many parameters were still not given green status over the years, but the results improved. The trend for Orgs 1,2, and 6 is downward, and for Org 3, it is basically unchanged, and the weighting limit is at the same level as Org 4 for 2019. The trend for 
Org 8 decreased in 2015-2018. The direction turned positive between 2018 and 2019, yet the improvement in the parameter results is still below the level when the SI analysis was implemented in 2015.

A comparison between the parameters results for the 171 municipalities that participated in the SI survey in 2019 and the results for the eight studied organizations in 2019 are shown in Table 1 . The table shows that Orgs 1-8 had a smaller proportion of red results in all parameters compared to the national results of all 171 participants. This is in line with [7], which noted that municipalities with more than 50,000 inhabitants had improved results, especially with a smaller proportion of red parameters than municipalities with fewer than 20,000. However, the proportion of green parameters for Orgs 1-8 was not larger for all parameters, and it was even lower for some of them, especially those that require long-term strategies and planning. The parameters "W and WS planning", "Climate adaptation and flood security", and "Status of W and WS fixed facilities" are three examples where none of the eight organization have green status. This is in line with SI results reports for 2015-2019 for the parameters with the largest red proportion nationally. See Table 1 for results from 2019.

Table 1. Proportion of red and green parameters for Orgs 1-8 and 171 organizations that participated nationally, in percent.

\begin{tabular}{|c|c|c|c|c|c|}
\hline Base Pillar & Parameters & $\begin{array}{c}\text { Proportion } \\
\text { of Red } \\
\text { Parameters } \\
\text { for Orgs 1-8 } \\
\text { in } 2019\end{array}$ & $\begin{array}{c}\text { Proportion } \\
\text { of Red } \\
\text { Parameters } \\
\text { for } 171 \text { Orgs } \\
\text { Nationally in } 2019\end{array}$ & $\begin{array}{c}\text { Proportion } \\
\text { of Green } \\
\text { Parameters } \\
\text { for Orgs 1-8 in } \\
2019\end{array}$ & $\begin{array}{c}\text { Proportion } \\
\text { of Green } \\
\text { Parameters } \\
\text { for } 171 \text { Orgs in } \\
2019\end{array}$ \\
\hline \multirow{7}{*}{$\begin{array}{l}\text { Sustainable } \\
\text { services } \\
\text { for users }\end{array}$} & $\begin{array}{l}\text { Healthy and safe } \\
\text { water }\end{array}$ & $2 / 8=25 \%$ & $44 \%$ & $25 \%$ & $31 \%$ \\
\hline & Water quality & $3 / 8=38 \%$ & $60 \%$ & $38 \%$ & $21 \%$ \\
\hline & Delivery security & $4 / 8=50 \%$ & $59 \%$ & $50 \%$ & $34 \%$ \\
\hline & $\begin{array}{l}\text { W and WS } \\
\text { planning }\end{array}$ & $1 / 8=13 \%$ & $41 \%$ & $0 \%$ & $18 \%$ \\
\hline & $\begin{array}{l}\text { Climate adaptation } \\
\text { and flood security }\end{array}$ & $3 / 8=38 \%$ & $58 \%$ & $0 \%$ & $3 \%$ \\
\hline & Satisfied users & $0 \%$ & $21 \%$ & $85 \%$ & $59 \%$ \\
\hline & Communication & $1 / 8=13 \%$ & $21 \%$ & $25 \%$ & $12 \%$ \\
\hline \multirow{4}{*}{$\begin{array}{l}\text { Environmental } \\
\text { sustainability }\end{array}$} & $\begin{array}{l}\text { Management with } \\
\text { finite resources }\end{array}$ & $3 / 8=38 \%$ & $67 \%$ & $50 \%$ & $21 \%$ \\
\hline & $\begin{array}{c}\text { Energy } \\
\text { management }\end{array}$ & $0 \%$ & $19 \%$ & $38 \%$ & $20 \%$ \\
\hline & $\begin{array}{l}\text { Environmental } \\
\text { requirements }\end{array}$ & $0 \%$ & $6 \%$ & $25 \%$ & $54 \%$ \\
\hline & Water asset & $0 \%$ & $15 \%$ & $6 / 8=75 \%$ & $32 \%$ \\
\hline \multirow{3}{*}{$\begin{array}{l}\text { Sustainable } \\
\text { resources }\end{array}$} & $\begin{array}{c}\text { Status of } W \text { and } \\
\text { WS fixed facilities }\end{array}$ & $5 / 8=63 \%$ & $78 \%$ & $0 \%$ & $5 \%$ \\
\hline & $\begin{array}{l}\text { Stability of } \\
\text { operation }\end{array}$ & $1 / 8=13 \%$ & $33 \%$ & $38 \%$ & $28 \%$ \\
\hline & $\begin{array}{l}\text { Staff resources and } \\
\text { competence }\end{array}$ & $1 / 8=13 \%$ & $10 \%$ & $13 \%$ & $21 \%$ \\
\hline
\end{tabular}

Taking a closer look at the results of Orgs 1-8 regarding these three parameters, we can see that one organization was red in "W and WS planning"; i.e., seven organizations had improved results. For the parameter "Climate adaptation and flood security", five organizations have yellow status, indicating that the improvement or maintenance of their 
result was unchanged. For the parameter "Status of W and WS fixed facilities", only three of the eight improved their results to yellow status.

On the national level, the lack of long-term planning in many cases leads to an assessment of SI parameters as red. This applies to overall $\mathrm{W}$ and WS planning as well as action and renewal plans. For example, $40 \%$ of the 171 participating municipalities do not have a $\mathrm{W}$ and WS plan. Only $5 \%$ report having a timed renewal plan for the pipeline network (Table 1). The SI results clearly show that challenges linked to long-term planning, investigation, and the capacity to run projects were perceived to be the most difficult to address [7].

The result of the parameter "W and WS planning" was evaluated based on whether there were plans, strategies, or policy documents to rely on when it comes to water supply, wastewater management, and stormwater. The assessment is also based on whether there is an overall management approach to, for example, climate adaptation. Approximately $20-25 \%$ of municipalities with more than 50,000 inhabitants were assessed as red for SI parameters due to the lack of long-term planning [7].

In this study, $13 \%$ had red status (Table 1). None of the eight organizations were assessed as green for the parameter. Still, all believed that the use of strategic planning contributes to development toward sustainability. The manager of Org 3 said, "It is a prerequisite that you have a long-term plan to build a society towards sustainability". The manager of Org 4 said, "Since strategic planning assumes that we want to be sustainable, we are far from sustainability today, and that is what we should focus on."

Of the 171 municipalities, 58\% were assessed as red for the parameter "Climate adaptation and flood security" on a national level. Green status for this parameter requires a vulnerability analysis with an action plan with a strategy for flood protection for new construction, and fewer than one flood over a 5-year average. The lack of a vulnerability analysis with an action plan makes the proportion of red so large. Larger municipalities, regardless of their organizational form, have significantly better results than small municipalities [7].

The factors that caused the significant proportion of red in the two parameters "Climate adaptation and flood security" and "Status of W and WS fixed installations" for the eight studied organizations were investigated via the interviews.

Orgs $3,4,5,7$, and 8 reported that they did not have an assessment of green for the parameter "Climate adaptation and flood security", because this is a cross-administrative issue involving many administrations that must provide resources; consequently, it is difficult to produce an action plan. The head of Org 8 explained this further as follows: "The stormwater issue concerns several parties. The W and WS organization, for example, is responsible for the pipe network's capacity up to a certain level, but not for extreme precipitation events. The pipe network must not be able to do that. If there is an excessive downpour over what the pipeline network is able to handle, management must take place through urban planning by creating delay surfaces, flood surfaces, open waterways, and so on. That is, in the event of a sudden cloudburst, several parties own that issue, and joint action is required. We can do some of the measures, and it requires that other parties over which we have no control do their part. It isn't easy to make an overall action plan".

Org 1, the smallest of the surveyed organizations, with about 35,000 inhabitants, has managed its stormwater. According to the organization's head, it took three to four years to get to where they are today, and their action plan was intended to be ready in 2020 . Contrary to what was reported in [7], "larger municipalities, regardless of organizational form, have significantly better results than small municipalities".

The parameter "Status of W and WS fixed facilities" is the biggest challenge for organizations because it has a large proportion of red, and the required improvement measures are resource-intensive (Table 1). This parameter demands financial foresight in the form of a multi-year budget and a long-term financial plan for investment in addition to the status of all parts of the W and WS system (pipe network, waterworks, sewage treatment plants, and pumping stations). The large proportion of red results is due to not meeting the requirement for financial foresight for investments, and many municipalities 
have not analyzed their need for renewal while the rate of renewal is low. This is in line with what the head of Org 4 said in the interview: "We have not analyzed the condition of the wastewater pipe network that we have filmed". It was found that even municipalities that have a long-term financial plan cannot carry out renewal projects as needed due to the need for resources for new development [7]. The tax equalization system in Sweden does not compensate municipalities for poorly maintained fixed assets, according to the state office (2014) [13]. Thus, municipalities cannot expect to receive state support to cover the costs that arise due to neglected maintenance. Despite these circumstances, municipalities still fail to plan or adequately maintain their water and sewage facilities [14].

The results for the parameter "Status of W and WS fixed facilities" for Orgs 1-8 is presented in Figure 11 for 2015, 2017, 2018, and 2019. Nine questions, Rs1-Rs9 (Appendix A, Figure A3) were answered by each organization to get the value (color) of this parameter. To get green status, questions Rs1 and Rs2 must have green status, a maximum of two other questions has yellow status, and no question has red status. Figure 11 has a section of Figure 8 showing the results of the parameter "Status of W and WS fixed facilities".

\begin{tabular}{|c|c|c|c|c|c|c|c|c|c|c|c|c|c|c|c|c|c|}
\hline & \multicolumn{3}{|c|}{ Org 1} & Org 2 & \multicolumn{3}{|c|}{ Org 3} & $\operatorname{Org} 4$ & \multicolumn{3}{|c|}{$\operatorname{Org} 5$} & Org 6 & \multicolumn{3}{|c|}{ Org 7} & \multicolumn{2}{|l|}{ Org 8} \\
\hline & & Param & leters & Parameter resultat & & Paramete & & Parameter resultat & & Parameter & & Parameters & Para & ameter & & Parameters & \\
\hline & 2015 & \begin{tabular}{l|l|l|}
52017 & 2 \\
\end{tabular} & \begin{tabular}{|l|}
2018 \\
2019 \\
\end{tabular} & \begin{tabular}{|l|l|l|l|l|}
2015 & 2017 & 2018 \\
\end{tabular} & 20152 & $2017 \mid 2018$ & \begin{tabular}{|l|l|}
8 & 2019 \\
\end{tabular} & \begin{tabular}{|l|l|l|l|l|}
2015 & 2017 & 2018 & 2019 \\
\end{tabular} & 2015 & \begin{tabular}{|l|l|}
2017 & 2018 \\
\end{tabular} & 2019 & 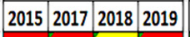 & \begin{tabular}{|l|l|}
2015 & 2017 \\
\end{tabular} & & 2019 & \begin{tabular}{|l|l|l|}
2015 & 2017 & 2018 \\
\end{tabular} & 8019 \\
\hline $\begin{array}{l}\text { The status of W and WS } \\
\text { fixed facilities }\end{array}$ & 1 & 1.2 & \begin{tabular}{|l|l|}
1.2 & 1.3 \\
\end{tabular} & \begin{tabular}{|l|l|l|l|}
1.78 & 1.56 & 1.3 & 1.3 \\
\end{tabular} & 0.9 & \begin{tabular}{l|l}
1 & 1.2 \\
\end{tabular} & 1.3 & \begin{tabular}{|l|l|l|l|}
1.1 & 0.44 & 0.55 & 0.78 \\
\end{tabular} & 1 & \begin{tabular}{|l|l|}
1.2 & 1.1 \\
\end{tabular} & 1.3 & \begin{tabular}{|l|l|l|l|}
1 & 1.33 & 1.33 & 1.33 \\
\end{tabular} & \begin{tabular}{|l|l|}
1.2 & 1.3 \\
\end{tabular} & 1.2 & 1.6 & \begin{tabular}{|l|l|l|}
1.33 & 1.2 & 1.2 \\
\end{tabular} & 1 \\
\hline
\end{tabular}

Figure 11. Results for parameter "Status of W and WS fixed facilities" for Orgs 1-8.

However, Orgs 3,7 , and 8 have yellow status with weighting limits of 1.3, 1.6, and 1.44 , respectively, and they were satisfied that they tackled the problem and were in good standing. The other five organizations still have red status for the parameter, which is in line with [14]: "the municipalities still fail to plan or adequately maintain their water and sewage facilities". The weighting ratio for Orgs 1,2, 5, and 6 is 1.3, because only one of the nine questions that evaluate this parameter has red status. Org 1 has its facilities in good order and got very well in phase with them, as the manager stated in the interview. However, the reason for the red status of this parameter is the red status for question Rs5, "Renewal rate pipe network water 5-year average should be $>0.7$ " (Figure 5); they had $<0.6$. Org 5 also has red status for Rs 5 for the same reason. The manager of Org 5 said, "We have an excellent status in our all works, and we have plans to maintain and improve the works that show the slightest sign of deterioration". Orgs 5 and 8 do not share the image of failing to plan and maintain their W and WS facilities as many other municipalities in Sweden do, as mentioned in [14]. On the other hand, Org 4 has a low weighting limit of 0.78 , and the manager explained this as follows: "We also noticed that we belong to municipalities that do not have renewal plans. But we are working right now and making these plans and prioritizing them as well, and we have a pretty good view of our facilities' status. However, we have not analyzed the condition of the pipeline network that we filmed." This is in line with [7], which reported that many municipalities have not analyzed their need for renewal.

\subsection{Strategies Used by Six Organizations for Managing Their Activities to Eliminate the Shortcomings Identified by SI}

There are differences in how far various municipalities improved their results and eliminated the shortcomings that the SI identified, and these differences are obvious in Figures 8-10. However, in the interviews with the heads of the organizations, they talked about the strategies they apply and what they do to eliminate those shortcomings. Org 1 focuses on where it should spend its time and chooses "easy-to-access" problems when it has time. Org 3 considers working with the various strategic plans that are missing that affect the SI results. It monitors the organization's annual activities and results, and the management team decides on the changes that need to be made for the next year or the long term. Org 4 lists the shortcomings it needs to improve, based on the SI results: 
"We use SI to know which plans and which measures we should start with, and we take questions that we think are most important to make them green." Org 5 conducts an annual review of SI results and includes the shortcomings in its activities plan as priorities. The organization prioritizes questions that are most important and where it is appropriate to do something. The status of the question, either red or yellow, governs the choice of what to improve. Based on dialogue about and knowledge of the business and the overall competence within the organization, Org 7 looks at what is relevant and what is easy to fix and chooses particular issues to improve results. For example, the organization decided to make a water plan to get a yellow or green assessment. It also improved the result for the parameter "Water planning" from red in 2015, 2017, and 2018 with a weighting limit of one to yellow in 2019 with a weighting limit of 1.6 (Figure 8). Org 8 does not use the SI tool to analyze and plan its activities, and it does not use the tool to compare itself with others or look at their results. The manager of Org 8 said, "We have a strategy for initiating improvement work and planning it based on our company's strategy, the business area's strategy, and our activities plan, and then we go into our budget work."

The authors indicated some strategies that studies have shown are essential for the development of W and WS operations. These strategies were included in the sub questions to clarify whether the organizations used them. Implementing measures to motivate staff [15], integrating politicians into the business, benchmarking, and collaborating, especially on long-term and renewal planning [7,12], are some of the strategies.

\subsubsection{Measures to Motivate Staff}

Many motivational measures, such as setting goals for employees, ensuring that employees feel they are treated fairly, letting employees complete their work, and providing valuable rewards that have scientific support can motivate the staff and increase participation in work improvements [15]. The present study found that most of the interviewed organizations motivate their staff in line with some of the methods reported in [15]. For example, Org 1 supports its staff through dialogue and information to increase their commitment. At Org 3, the manager motivates the staff by using contributions for work improvement, as part of their salary discussion. At Org 4, establishing projects and increasing staff members' involvement in projects improve the organization's results. Org 5 offers additional time and assigns staff members concrete and prioritized projects to increase their participation in improving the SI results. Finally, by establishing specific goals and deadlines for projects, Orgs 7 and 8 increase staff participation.

\subsubsection{Integrating Politicians into the Business}

One of the essential strategic needs of municipal W and WS organizations is discussions between business leaders and policymakers around priorities and investments. One of the fundamental purposes of developing the SI is to provide a background for this discussion by showing them the strengths and weaknesses of W and WS operations. A proper compilation of SI survey results could simplify this task and contribute to making politicians understand the problems [8]. The interviews revealed that most of the organizations did not fully utilize this very important advantage of the SI results.

Orgs 1, 3, 4, 5, and 7 noted that they have confidence in the SI tool's positive role if it is used as a basis for discussion between the organization's leadership and politicians. They have used the result reports as a basis for discussion a little, but not as much as they would like.

Orgs 3, 5, and 7 integrate politicians in their improvement work in different ways. Org 3 integrates politicians by having training days, development days, and various meetings with the technical committee and the working committee. Thus, politicians become involved in thinking and planning. Org 5 integrates politicians through a planning management model. This means that politicians are involved in making certain decisions and investing resources when they start certain projects. It starts with the municipal leadership setting up a project directive for those who will work on the project. It determines what is to 
be achieved, who is responsible, what resources are available, and how much it will cost. Org 7 integrates politicians in its improvement work by addressing the relevant issues in SI. The organization informs them and have dialogues with them about what needs to be done.

Org 4 believes it needs to stimulate politicians and present SI to them more so they can understand it is a good tool. Org 5 also thinks it needs to improve its use of SI results and analyses in dialogue with politicians and the board and/or committees. The managers of Orgs 5 and 7 think they do not have a complete picture when they show how their results are related to other municipalities, and Org 7 thinks it is too complicated to set up. All of the organizations confirmed that they do not believe that SI has had much influence on strategic discussions or work between leadership and the board at the political level, because they have not used it very much. Org 3 believes that in the long term, the SI can influence strategic work between leadership and the board at the political level.

\subsubsection{Using the SI Survey Results as Business Development Support}

One of the expectations of SWWA was that W and WS organizations would use the SI survey results as business development support for other purposes, such as (a) comparing, planning, evaluating, and analyzing necessary measures, etc.; (b) identifying recruitment needs; (c) reviewing investment needs; and (d) utilizing long-term financial planning and tariffs.

Orgs 1, 3, 4, 5, and 7 noted that they use their SI survey results to a lesser extent but want to use them more. They use the results mostly to see how they are compared to others when making plans and projects, but not for the purposes mentioned above. Orgs 1, 3, 4, 5, and 7 agree that the SI has good potential and want to use it for all purposes.

Org 4 requested improvements to the data downloaded from VASS-SI. The manager said they wanted to see more graphs per question and see their own notes a little more to remember the following year how they reasoned during the self-evaluation. The manager said it would have been good to write more and get a little better support from the tool itself. The head of Org 7 wanted to have a follow-up of several years instead of picking out for each year. Org 8 does not use these reports; instead, it may take individual key figures and compare them to find out how things are going for other organizations.

\subsubsection{Benchmarking for Improvement}

According to [16], those who decide to benchmark can concentrate on improvements and upgrades (they will not need to reinvent the wheel). Through benchmarking, an organization can identify where it is and where it wants to be [17]. Benchmarking is a process that allows organizations to improve their results compared to an inspiring existing idea [18]. However, most of the organizations surveyed in this study do not use benchmarking against other organizations to get inspiration on the SI indications. One reason, according to the head of Org 1 , is not having time to do benchmarking. The head of Org 5 said the SWWA website was difficult to use for benchmarking with other municipalities and suggested that a background such as that shown in Figure 8 in this study should be available on the national level.

\subsubsection{Collaborating to Improve Parameter Renewal Planning}

There are several motives for collaboration: (1) to achieve competence; (2) to meet the increased demands on the business due to climate change, technological development, and the needs of end customers; (3) to improve service to end customers; (4) to optimize operations and find economies of scale to better meet financial requirements; (5) to create a more stable organization; and (6) to achieve better resource utilization [12]. According to SWWA, creating strong W and WS organizations is crucial in the long term. This means that municipalities and companies need to develop cooperation with others [3]. However, none of the interviewed organizations collaborate with neighboring municipalities when it comes to renewal plans. Orgs 3 and 4 collaborate with 13 municipalities in the region by having meetings, sharing experiences, and producing the SI survey but not improving the parameter renewal planning results. Org 7 has reviewed collaboration opportunities, 
but they have not yet materialized. It tries to find joint areas for collaboration through meetings, but no progress has been made to solve any problems. Org 8 collaborates with other neighboring municipalities on several issues (not based on SI), but it does not have an orderly purchase of services.

According to [19], all barriers to achieving collaboration should be removed. The biggest obstacles to collaboration between municipalities can sometimes be informal, but there are also concrete problems. The rules on balance sheet requirements and legal barriers to standard tariffs and capital management must be changed. Contrary to what was reported in [19], this study found that none of the obstacles mentioned above were reasons for not collaborating. Only the lack of time was mentioned by the head of Org 1 .

\subsection{Who Performs the Improvement Work and How It Is Financed?}

\subsubsection{Responsibility and Personal Competence}

The structure of a municipal W and WS organization with the traditional form and active ownership (Figure 12) consists of municipal councils (parliament), a municipal board (government), a technical committee, and a technical office. The W and WS organization is part of the technical office. The technical committee has the council's task of providing, operating, and developing the W and WS operations in the municipality. The committee makes decisions based on the technical office's documentation and develops the budget, and then, the municipal board approves the decisions and sets the tariffs [6].

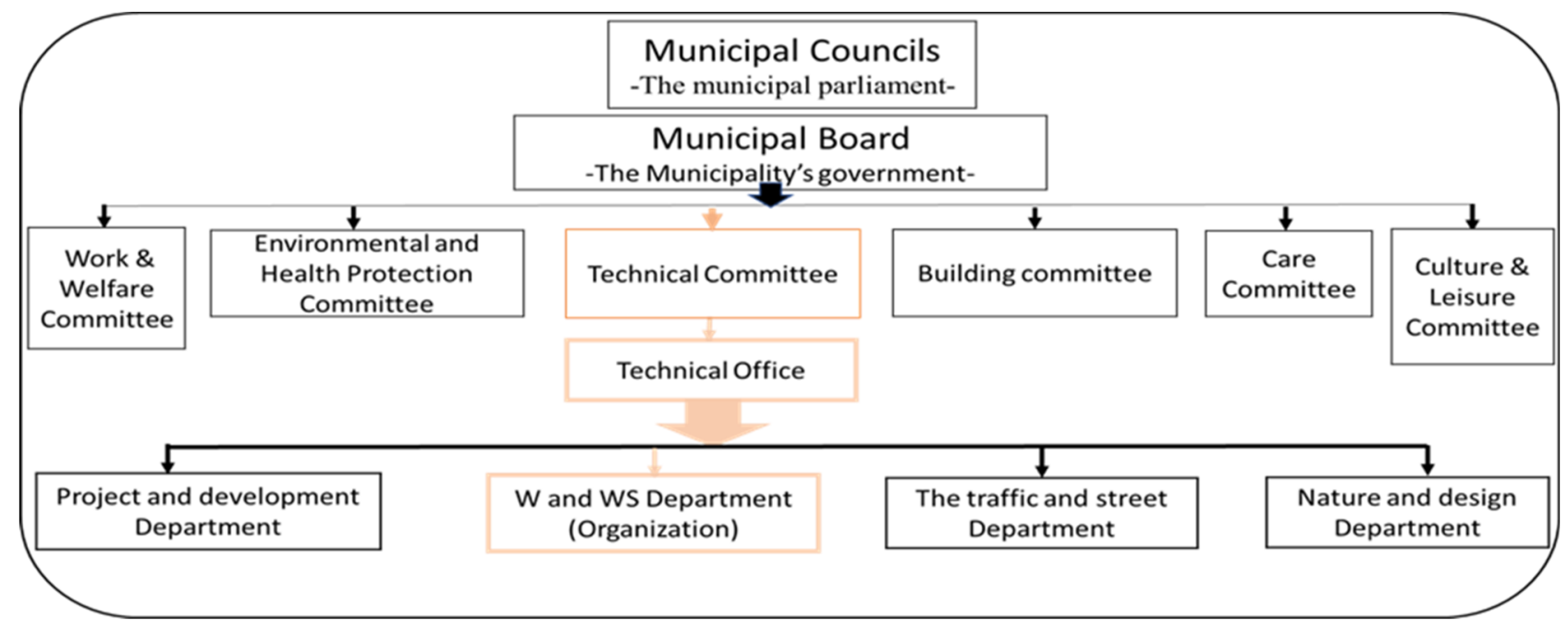

Figure 12. Committees that are part of the municipal structure. Highlighted in pink is the structure of the traditional form of the W and WS organization.

Thus, the interviewees in this study were also asked who owns the problem and is primarily responsible for making the entire business sustainable.

According to the heads of Orgs 1, 3, 4, 5, and 7, which have the traditional organizational form, the technical committee (politicians) has the primary responsibility to make the entire business sustainable, and the technical office has the primary responsibility for ensuring sustainability. Thus, the technical committee is responsible for ensuring that the technical office meets the sustainability objective, while the organization's managers, together with their staff, do the work. The head of Org 4 said, "The head of the technical office, who is my head, is responsible for maintaining sustainability. However, the technical committee is at the forefront, and the ultimate responsibility lies with the technical office's head. But then it is me and all the employees who are obliged to apply it." At Org 8, which is part of a multi-utility, the main responsibility lies with the CEOs. Those who ensure and strive for sustainability are business area managers, together with their staff. The head of Org 8 said, "The ultimate responsibility lies thus with the president of the group firm. But then we as managers have a business responsibility, which I have, for example, as 
a business area manager for $\mathrm{W}$ and WS. I am responsible for ensuring that we conduct sustainability work within my business".

According to [20-22], the traditional form of organization with active ownership is suitable for long-term planning. The leadership within the organization can, among other things, employ competent staff who can take responsibility for strategic sustainability projects [20]. Thus, active ownership means that the municipal leadership, together with the technical office leadership, ensures that fixed assets are managed by good financial management and personnel and financial resources are managed for strategic planning activities [6].

The following is a summary of responses from managers clarifying how W and WS organizations get politicians to ask for what is needed and, if necessary, increase the tariffs.

According to the managers, the technical committee should understand the problems that the municipality faces through dialogue. The W and WS organization must ensure that it has a detailed and specific background to describe the situation and the consequences of what could happen if nothing was done. The managers must point out the ground position with the help of specific key figures and talk about what could be achieved if the proposed measures were implemented.

All of the organizations reported that they had not experienced any problems with politicians. However, it also came out that they cannot get what they need and request from the politicians. The head of Org 3 said, "The investment budget is handled in budget preparation at the municipal level. And at that level, many other issues are also discussed as schools, elderly care, etc. Therefore, it can be much more difficult to reach with the $\mathrm{W}$ and WS needs".

The parameter "Personnel resources and competence" focuses on access to competent personnel for all $\mathrm{W}$ and WS organization activities and what recruitment opportunities look like. The outcome of the SI survey in 2020 was that at the national level, $25 \%$ of the organizations were green ( $21 \%$ in 2019$)$, i.e., they have both needed skills and personnel resources; $65 \%$ were yellow ( $69 \%$ in 2019$)$, i.e., they have difficulty with the availability of skills of key people who work with planning and ordering functions, project managers, and construction managers; and 10\% of the organizations lacked both competence and capacity.

The main reason the level of investment is too low, according to [3], is that many $\mathrm{W}$ and WS organizations lack the internal capacity to carry out necessary projects. Therefore, municipalities need to strengthen their W and WS organizations significantly to be able to handle the investment needs.

The outcome for the parameter "Personnel resources and competence" for the interviewed organizations is shown in (Figure 13). It has a section in Figure 8.

\begin{tabular}{|c|c|c|c|c|c|c|c|c|c|c|c|c|c|c|c|c|c|c|c|c|c|c|c|c|c|c|c|c|c|c|c|c|}
\hline & \multicolumn{4}{|c|}{ Org 1} & \multicolumn{4}{|c|}{ Org 2} & \multicolumn{4}{|c|}{ Org 3} & \multicolumn{4}{|c|}{ Org 4} & \multicolumn{4}{|c|}{ Org 5} & \multicolumn{4}{|c|}{ Org 6} & \multicolumn{4}{|c|}{ Org 7} & \multicolumn{4}{|c|}{ Org 8} \\
\hline & \multicolumn{4}{|c|}{ Parameters } & \multicolumn{4}{|c|}{ Parameter resultat } & \multicolumn{4}{|c|}{ Parameters } & \multicolumn{4}{|c|}{ Parameter resultat } & \multicolumn{4}{|c|}{ Parameters } & \multicolumn{4}{|c|}{ Parameters } & \multicolumn{4}{|c|}{ Parameters } & \multicolumn{4}{|c|}{ Parameters } \\
\hline & 2015 & 2017 & 2018 & 2019 & 2015 & 2017 & 2018 & 2019 & 2015 & 2017 & 2018 & 2019 & 2015 & 2017 & 2018 & 2019 & 2015 & 2017 & 2018 & 2019 & 2015 & 2017 & 2018 & 2019 & 2015 & 2017 & 2018 & 2019 & 2015 & 2017 & 2018 & 2019 \\
\hline $\begin{array}{l}\text { Staff resources \& } \\
\text { competence }\end{array}$ & 1.3 & 1.5 & 1.74 & 1.74 & 1.9 & 1.95 & 1.9 & 1.82 & 1.3 & 1.3 & 1.5 & 1.5 & 1.3 & 1.2 & 1.3 & 1.3 & 1.7 & 1.8 & 1.8 & 1.9 & 1.7 & 1.4 & 1.4 & 0.96 & 1.4 & 1.2 & 1.3 & 1.3 & 1.8 & 1.74 & 1.04 & 1.87 \\
\hline
\end{tabular}

Figure 13. Result for parameter "Personnel resources and competence" for organizations in this study.

Figure 13 shows that Org 5 has green status and Org 6 has red, accounting for $12.5 \%$ each. The rest of the organizations, which account for $75 \%$, have yellow status. All six interviewed managers stated that they had sufficient competence and carry out most of the work under their own management. If necessary, they also hire consultants when they do not have time, as in Org 7, or for special investigations when other skills are required, as in Org 4. Five of the six organizations have a relatively high weighting limit. Org 5 monitors and receives knowledge that SWWA provides through publications and courses. It has carried out reorganization in its business and created a central finance function with accounting economists and controls. Their task is to ensure that the business develops, i.e., they continuously assess whether they have the resources and sensibly use the money. 
Orgs 3, 4, and 8 are involved in research projects and collaborate with research groups at universities and national research programs, such as Mistra InfraMaint [23].

\subsubsection{Methods of Financing Shortcomings and Managing Fixed Assets}

The operation of the Swedish W and WS sector since the 1970s has been financed by user charges regulated by the cost price principle [24]. To protect users from monopoly pricing, the Public Water Services Act (2006) mandates that the result and financial position of the operation must be determined according to generally accepted accounting principles (GAAP) and should be reported separately for the W and WS business [25].

According to [14], it is difficult to raise the tariff for W and WS operations, even though municipal W and WS organizations have complete responsibility for the operations. However, the heads of all six interviewed organizations did not agree with what was reported in [14] and raised the tariff according to their assessment of needs. The head of Org 1 said, "We have raised the rate continuously for many years to cover new costs of investments and future operating maintenance and capital costs of our assets". Org 1 has a relatively high tariff and is in the top three of 13 municipalities in its county: "If we had not raised the tariff, we could not handle the basic maintenance and future investments". All interviewed organizations noted that there is a link between long-term sustainability and active demands to raise the W and WS tariff. This connection was clarified by the head of Org 8: "When we, for example, plan to adapt the wastewater treatment plant (WWTP) for climate impact, for the growing municipality, for new requirements on the degree of treatment, etc. Then, we plan for long-term sustainability, and it costs a lot of money. W and WS fees are, of course, raised in that case". Thus, the adaptation process for all of these factors, which are the base pillars of long-term sustainability, need resources in terms of sufficient and skilled staff, a strong economy, and a well-functioning and robust organization [3].

Since W and WS fees are based on budgeted assumptions that are predetermined, it is not surprising that these fees sometimes exceed the costs incurred to perform those services. Accordingly, a study [19] showed that of 34 municipalities, $80 \%$ had a surplus in their operations.

The Public Water Services Act (2006) and its regulations lack specifications on which investment objects are permitted to be allocated to funds. This means that W and WS organizations end up in line with the law's intentions; thus, they are not funded for general investment but for a specific investment [19]. The cost price principle makes it possible to set aside funds for new investments but not reinvestment and exploitation. As an example of applying this principle, Org 4 proposed an increase in the tariff of approximately $3 \%$ now and in the next few years, because it is investing in a fund for a new WWTP: "We thus fund money, and we can do this because we must go, plus if we know what the money is to be used. Therefore, we can avoid raising the tariff in shock when investing about half a billion SEK in the new WWTP. We may need to submit a few percent more to the tariff to do a little more when it comes to reinvestments". Funding by Org 4 is in line with what the Växjö municipality did successfully when SEK 120 million of a total SEK 450 million was put in an investment fund for implementing its future water supply project in 2009 [20]. Org 3 , according to the manager, decided not to charge a fee to cover future costs, and it established an investment fund with allocated funds from overdrafts in the consumption charge for a few years. The Water Services Act states that organizations can use a possible overdraft within three years, but Org 3 chose to lock the money in an investment fund to be used for two selected investment projects. The head of Org 3 stated, "It may not be used for renewal, according to the Water Services Act. The Water Services Act has a shortcoming there, one might think. On the other hand, you can use them for new investments that benefit the entire collective, for example making investments in the waterworks".

Some points emerged from [14] and the managers of the interviewed organizations against the current legislation. The manager of Org 5 said, "We have problems with current legislation. It demands that future maintenance needs be clearly defined. It should be 
clear what the tariff is to be used for and that it shows that the benefit goes to everyone. And according to current legislation, it is the current rate level that governs both investment and reinvestment costs". According to [14], there is injustice between generations because of the current low level of reinvestment. This means that residents who have lived in the municipality have benefited from an underpriced service in recent decades, while future residents will have to pay additional fees. Org 8 agrees with this concept of injustice between generations. Its manager stated that the current W and WS charging system does not cover future maintenance costs, and it is not easy to increase it so that it does cover those costs. However, according to the manager and in line with Orgs 3 and 5, it would be easier to create funds for future reinvestments. Orgs 3, 5, and 7 also think that the legislation's not allowing the creation of funds for reinvestment will cause inequality between the generations. The head of Org 8 said, "There are still significant risks with the large loans we have, because an interest rate increase will mean a sharp rate increase. Those who pay the fees today have significantly benefited from the low interest rates that have been in recent years. On the other hand, the next generation may be disadvantaged if interest rates rise".

Orgs 8 and 5 intend to have this generation pay tariffs that will also cover future costs, thus promoting justice between the generations. Org 7 emphasized that a legislative change in the Water Services Act is required: "We must set aside money for an investment fund for new investment, covering the entire W and WS business, including reinvestment. If we also had to set aside a reinvestment fund, it would make it much easier and even out the year's costs". Org 7 is investing very heavily in both new and existing facilities. Its loan debt increased from SEK 200 million in around 2010 to SEK 1.2 billion in 2020. It was possible to borrow such large amounts due to the significant need for investment, the depreciation of many old facilities, and the fact that the Water Services Act was designed so that the business should be plus or minus zero. The head of Org 7 said, "We are building a new waterworks to compensate for population growth and the main water pipeline network with a larger diameter. But the rate of renewal of the pipeline network is low. Money for renewal must come in, we cannot wait for depreciation of 30-40 years, and the only way to do that is to create funds for reinvestment".

In an interview with a lawyer at SWWA in December 2020 [26], the lawyer stated that the Water Services Act (2006) causes some uncertainty among W and WS principals regarding how to establish a fund. The principals have expressed the desire to use a fund for reinvestments, not only for the new investments. It would be easier for the principals if it was possible to use the fund for reinvestment as well, the lawyer said, but those municipalities should have thought of the reinvestment plans earlier, as such action is regularly wrong. It would also create stress for the W and WS collectives if they had to pay large sums to cover these significant investments. The collective should not be responsible for the entire investment. Thus, municipalities must establish an even distribution of expenses over time to prevent an unfair distribution of costs between subscribers and principals, the lawyer said [26].

\section{Conclusions}

It takes time to improve the performance of a utility and make it sustainable. SI results reports at the national level have shown that the SI survey results did not improve much nationally through 2016-2019 (Figure 4) [7]. This study found that the results for the eight investigated municipalities in 2019 were better compared with the national result (Table 1). Orgs 1-8 have smaller proportions of red status in all parameters compared to the national results of all 171 participants. This is in line with [7], which noted that municipalities with more than 50,000 inhabitants had improved results compared with municipalities with fewer than 20,000. However, the proportion of green parameters for Orgs 1-8 was lower on those parameters that require long-term strategies and planning. The parameters " $\mathrm{W}$ and WS planning", "Climate adaptation and flood security", and "Status of W and WS fixed 
facilities" are three examples where none of the eight organizations have green status. This is in line with national results.

In total, $20-25 \%$ of all 171 participants with more than 50,000 inhabitants were assessed as red for the parameter "W and WS planning" compared with $13 \%$ for this study.

None of the Orgs 1-8 were assessed as green for the parameter "W and WS planning". Still, all believed that the use of strategic planning contributes to development toward sustainability.

More than half (58\%) of 171 SI participants on a national level compared with $38 \%$ for Orgs 1-8 were assessed as red for the parameter "Climate adaptation and flood security". The lack of a vulnerability analysis with an action plan makes the proportion of red so large. According to the interviewed managers, it is difficult to produce an action plan because the stormwater issue is a cross-administrative issue involving many administrations that must provide resources.

The large proportion (78\% on national level and $63 \%$ for Orgs 1-8) of red results for the parameter "Status of W and WS fixed facilities" is due to not meeting the requirement for financial foresight for investments, and many municipalities have not analyzed their need for renewal, while the rate of renewal is low $(<0.7)$.

In this study, three organizations out of eight have yellow status and were satisfied that they tackled the problem and were in good standing.

The tax equalization system in Sweden does not compensate municipalities for poorly maintained fixed assets. Thus, municipalities cannot expect to receive state support to cover the costs that arise due to neglected maintenance [13].

The change trend for SI parameters during 2015 and 2017-2019 for Orgs 1-8 shows that three organizations, Orgs 4, 5, and 7, improved their results, and Org 5 had the best results.

Orgs 1-8 use established methods to motivate staff and increase participation in work improvements. However, they did not use benchmarking to get inspiration on the SI indications.

Orgs 1, 3, 4, 5, and 7 believe in the SI tool, agree that SI has good potential, and want to use the results for all purposes for which they are intended, such as for comparison, planning, evaluation, analysis of necessary measures, and reviewing investment needs. They have confidence in the SI tool's positive role if used as a basis for discussion with policymakers and have used their results reports to varying degrees but not as much as they would like. However, they do not believe that SI has influenced much strategic work between leadership and the board at the political level, because they have not used it very much.

Orgs 5 and 7 think they do not have a complete picture when they show how their results are related to other municipalities, and Org 7 thinks it is too complicated to set up.

For Orgs 1, 3, 4, 5, and 7, which have a traditional form of organization, the technical committee is responsible for ensuring that the technical office meets the sustainability objective. However, the heads of the W and WS organizations together with their employees are those who do the work.

For Org 8, which has a multi-utility organizational form, the main responsibility lies with the CEO, and those who ensure sustainability are business area managers, together with their staff.

All the surveyed organizations have sufficient competence to carry out most of the work by their own staff except for Org 1, which expressed a need for more competent staff. The organizations also use consultants when special skills are required or when they do not have time.

The W and WS services are financed by user fees, and the heads of all six interviewed organizations raised the tariff according to their assessment of needs. However, it should be clear what the tariff is to be used for and show that the benefit goes to everyone.

Orgs 3, 4, and 7 have locked money in investment funds from the overdrafts in the consumption charge. However, according to the Public Water Services Act (2006), these funds can only be used for specific new investments that benefit the entire collective, not for general investment. 
There is injustice between generations because of the current low level of reinvestment. This means that the next generation will pay for the underpriced services the current generation benefited from.

The manager of Org 8 noted that the current W and WS charging system does not cover future maintenance costs, and it is not easy to increase the fees so that these costs will be covered.

Orgs 1-8 believe that a reinvestment fund would even out the year's costs and make it much easier to reinvest. They also emphasized that the legislation's not allowing the creation of funds for reinvestment will cause inequality between the generations.

The heads of Orgs 8 and 7 think there are significant risks with the large loans they have because an interest rate increase would mean a sharp increase in fees, thus increasing the injustice.

The head of Org 7 emphasized that money for renewal must come in, and one way to do that is to create funds for reinvestment. The manager also emphasized that a legal change in the Water Services Act is required.

The factor that mainly causes shortcomings and the red status of the parameter "Status of fixed assets" is money. This became clear and was emphasized by the respondents' complaints about deficiencies in the legislation and the need for reinvestment funds.

Supplementary studies should be conducted to further investigate the two parameters "Climate adaptation and flood security" and "Status of W and WS fixed facilities". Both parameters require long-term strategies and planning and have a direct impact on development toward sustainability. In addition, they still are the biggest challenges for the $\mathrm{W}$ and WS sector. Only four and seven organizations, respectively, out of 184 participating municipalities had green status for both parameters in the SI survey in 2020 [3].

Author Contributions: N.N. designed and performed the study, analyzed and interpreted the results, and wrote the paper. K.M.P. added many topics to the interview questions, contributed several valuable ideas and options, supervised the whole study, and provided much support and was always available when needed. All authors have read and agreed to the published version of the manuscript.

Funding: This research received no external funding.

Institutional Review Board Statement: Not applicable.

Informed Consent Statement: Not applicable.

Data Availability Statement: Not applicable.

Acknowledgments: The authors would like to express gratitude to Magnus Bäckström, an expert at SWWA, for all the work he did to contact his members. Without his support, it would have been impossible to do this study. We would like to thank the interviewees who devoted their time and contributed valuable input and knowledge to the study.

Conflicts of Interest: The authors declare no conflict of interest. 


\section{Appendix A}

\begin{tabular}{|c|c|c|c|c|c|c|c|c|c|c|c|c|}
\hline \multicolumn{13}{|c|}{ First base pillars: Sustainable services $f$} \\
\hline Parameter : Hea & thy \& safe water - $T$ & Th 1-3 & & & & & & & & & & \\
\hline \multirow{2}{*}{\multicolumn{4}{|c|}{$\begin{array}{l}\text { Th1- Percentage of routine water tests on the net } \\
\text { and at works that are not good (unfit) } \\
\text { Parameter: Water quality-Tv 1-3 }\end{array}$}} & \multirow{2}{*}{\multicolumn{4}{|c|}{$\begin{array}{l}\text { Th2- Percentage of unfit/ samples that have } \\
\text { been investigated }\end{array}$}} & \multirow{2}{*}{\multicolumn{5}{|c|}{$\begin{array}{l}\text { Th3-Simplified / complete MBA (Microbiological Barrier } \\
\text { Analysis), performed on all works }\end{array}$}} \\
\hline & & & & & & & & & & & & \\
\hline \multicolumn{4}{|c|}{$\begin{array}{l}\text { Tv 1- Percentage of routine, on the net exams } \\
\text { and on works with a valid result. }\end{array}$} & \multirow{2}{*}{\multicolumn{4}{|c|}{$\begin{array}{l}\text { Tv 2- The proportion of follow-up tests with } \\
\text { measures planned }\end{array}$}} & \multirow{2}{*}{\multicolumn{5}{|c|}{$\begin{array}{l}\text { Tv 3-All water quality complaints are recorded, controlled } \\
\text { and followed. It is enough to record time and place and } \\
\text { take the necessary actions for each complaint. }\end{array}$}} \\
\hline \multicolumn{3}{|c|}{ Parameter : Delivery security- TI 1-5 } & & & & & & & & & & \\
\hline $\begin{array}{l}\text { TI 1.Emergency } \\
\text { water planning }\end{array}$ & $\begin{array}{l}\text { TI 2- Emergency } \\
\text { volume/reservew } \\
\text { volume. }\end{array}$ & & \multirow{2}{*}{\multicolumn{3}{|c|}{$\begin{array}{l}\text { TI 3. How can the water } \\
\text { supply be maintained in } \\
\text { the event of a power } \\
\text { failure? }\end{array}$}} & \multirow{2}{*}{\multicolumn{4}{|c|}{$\begin{array}{l}\text { TI 4. Delivery interruption in the } \\
\text { network. Total shutdown time per } \\
\text { year/number of shutdown areas in } \\
\text { min/user, year }\end{array}$}} & \multirow{2}{*}{\multicolumn{3}{|c|}{$\begin{array}{l}\text { TI 5. Degree of utilization at the } \\
\text { waterworks max day (with serviced water) } \\
\text { for the works that supply at least } 20 \% \text { use }\end{array}$}} \\
\hline \multicolumn{3}{|c|}{ Parameter : W and WS - planing - Tp 1-10 } & & & & & & & & & & \\
\hline \multicolumn{2}{|c|}{$\begin{array}{l}\text { Tp 1. Is there a W and WS plan that } \\
\text { has been developed with an } \\
\text { overall management process and } \\
\text { which is well-rooted in politics }\end{array}$} & \multicolumn{5}{|c|}{$\begin{array}{l}\text { Tp 2. Does the plan include a } \\
\text { description of drinking water supply } \\
\text { and sewage management, including } \\
\text { the impact on water status }\end{array}$} & $\begin{array}{l}\text { Tp 3. Does the } \\
\text { plan contain a W } \\
\text { and WS policy or } \\
\text { equivalent }\end{array}$ & \multicolumn{3}{|c|}{$\begin{array}{l}\text { Tp 4.Does the W and WS } \\
\text { plan forms the basis for } \\
\text { decisions on financing } \\
\text { proposed measures }\end{array}$} & \multicolumn{2}{|c|}{$\begin{array}{l}\text { Tp 5. Does the W and WS- plan, } \\
\text { or the politically guiding } \\
\text { principles for W and WS } \\
\text { planning look over regularly? }\end{array}$} \\
\hline $\begin{array}{l}\text { Tp 6. Is there a } \\
\text { plan for expansion } \\
\text { of the public water } \\
\text { plant? }\end{array}$ & \multirow{2}{*}{\multicolumn{8}{|c|}{$\begin{array}{l}\text { Tp 7. Is there a plan of action for renewal needs of } 10 \text { years or longer, linked to both } \\
\text { the status and challenges of the plants in the form of climate adaptation, new } \\
\text { purification requirements, deteriorating raw water quality, etc.? At least the plan } \\
\text { should contain a rough estimate if, in the future less, equal, twice as much, three so } \\
\text { adaptation o flood security - Ta 1-3 much effort is needed compared to today. }\end{array}$}} & \multirow{2}{*}{\multicolumn{2}{|c|}{$\begin{array}{l}\text { Tp } 8 . \text { Is } \\
\text { there a } \\
\text { regional } \\
\text { water } \\
\text { supply plan }\end{array}$}} & $\begin{array}{l}\text { Tp 9. Is } \\
\text { there } \\
\text { Stormwater } \\
\text { strategy? }\end{array}$ & $\begin{array}{l}\text { Tp10. Is there a } \\
\text { strategy for } \\
\text { individual W \& WS } \\
\text { management? }\end{array}$ \\
\hline Parameter: Climate adaptation 0 flood security - Ta 1-3 much effort is needed compared to today. & & & & & & & & & & & & \\
\hline \multirow{2}{*}{\multicolumn{5}{|c|}{$\begin{array}{l}\text { Ta 1. Is there an investigation with an action plan } \\
\text { on social vulnerability as a result of more extreme } \\
\text { rainfall and rising levels in the sea, rivers and lakes? } \\
\text { Parameter :Satisfied users - Tn 1-4 } \\
\end{array}$}} & \multirow{2}{*}{\multicolumn{6}{|c|}{$\begin{array}{l}\text { Ta 2. Is there a clear strategy, in new construction and rebuilding, } \\
\text { for flood-safe height so that damage does not occur in houses } \\
\text { when stormwater systems are overloaded? }\end{array}$}} & \multirow{2}{*}{\multicolumn{2}{|c|}{$\begin{array}{l}\text { Ta 3. Basement flooding in the Water } \\
\text { activity area. (5-year average or } \\
\text { number per } 1000 \text { service } \\
\text { connections). }\end{array}$}} \\
\hline & & & & & & & & & & & & \\
\hline \multicolumn{6}{|c|}{$\begin{array}{l}\text { Tn 1. Is satisfaction measured for users in contact with W and WS? } \\
\text { According to what type of satisfaction survey (SKL or SCB)? } \\
\text { Parameter: Communication - Tk 1-3 }\end{array}$} & \multicolumn{4}{|c|}{$\begin{array}{l}\text { Tn } 2 . \text { Is user surveys used to make } \\
\text { improvements in the W and WS activities? }\end{array}$} & \multicolumn{2}{|c|}{$\begin{array}{l}\text { Tn 3. Satisfied water } \\
\text { users. }\end{array}$} & $\begin{array}{l}\text { Tn 4. Satisfied } \\
\text { wastewater users. }\end{array}$ \\
\hline \multicolumn{5}{|c|}{$\begin{array}{l}\text { Tk 1. Are operational disruptions and other important } \\
\text { information communicated effectively to citizens? }\end{array}$} & \multicolumn{4}{|c|}{$\begin{array}{l}\text { Tk 2. Is internal communication work even if both } \\
\text { fixed and mobile telephony are eliminated? }\end{array}$} & \multicolumn{4}{|c|}{$\begin{array}{l}\text { Tk } 3 . \text { Is internal communication work even if } \\
\text { both fixed and mobile telephony are } \\
\text { eliminated? }\end{array}$} \\
\hline
\end{tabular}

Figure A1. "Sustainable services for users" pillar, seven related parameters, group codes for parameters, and related questions (key figures). 


\begin{tabular}{|c|c|c|c|c|c|c|c|}
\hline \multicolumn{8}{|c|}{ Second base pillars : Environmentally sustainability. Consists 4 parameter. Each parameter consists of several questions (16 PCS. total) } \\
\hline \multicolumn{2}{|c|}{$\begin{array}{l}\text { Mr1: Proportion of recycled phosphorus from } \\
\text { WWTP to productive land. }\end{array}$} & \multicolumn{3}{|c|}{$\begin{array}{l}\text { MR 2: Sludge coming from WWTP in the } \\
\text { municipality is mainly used in the following way }\end{array}$} & \multicolumn{3}{|c|}{$\begin{array}{l}\text { MR 3: Is a systematic upstream work carried out to } \\
\text { reduce the sources of contaminants in the sludge and } \\
\text { the outgoing water? }\end{array}$} \\
\hline \multicolumn{8}{|c|}{ Parameter: Energy management- Me 1-5 } \\
\hline $\begin{array}{l}\text { Me 1:Me 1: Specific electrical energy } \\
\text { use for water production and } \\
\text { distribution ( } \mathrm{kWh} / \text { connected, year) }\end{array}$ & \multicolumn{2}{|c|}{$\begin{array}{l}\text { Me 2: Energy loss in the } \\
\text { form of water losses\% }\end{array}$} & $\begin{array}{l}\text { Me 3: Specific elec } \\
\text { energy use for sew } \\
\text { drainage and treat } \\
\text { [kWh / person, yea }\end{array}$ & & \multicolumn{2}{|c|}{$\begin{array}{l}\text { Me 4: Specific biogas } \\
\text { production from sludge } \\
\text { generated from the own } \\
\text { municipality. [kWh / person, } \\
\text { year] }\end{array}$} & $\begin{array}{l}\text { Me 5: High-quality specific } \\
\text { biogas use "exergy value", } \\
\text { ie gas + electricity [kWh / } \\
\text { person, year] }\end{array}$ \\
\hline \multicolumn{8}{|c|}{ Parameter :Environmental requirements- Mm 1-5 } \\
\hline $\begin{array}{l}\text { Mm 1: All regulatory requirements } \\
\text { for permits for water services } \\
\text { according to the Environmental } \\
\text { Code exist. -WWTP for }<200 \text { pe has } \\
\text { a permit from the municipality's } \\
\text { environmental committee.- } \\
\text { Notifiable WWTP for } 200 \text { and } 2000 \\
\text { pe are notified to the } \\
\text { environmental committee. WWTP } \\
\text { for } 2000 \text { pe is licensed. }\end{array}$ & \multicolumn{2}{|c|}{$\begin{array}{l}\text { Mm 2: The permit requirements } \\
\text { are followed for sewage treatment } \\
\text { plants incl. any regulatory } \\
\text { requirements for online surfing. - } \\
\text { The conditions in the permits for } \\
\text { WWTP / a compliant.- The } \\
\text { requirements for the notifiable } \\
\text { WWTP compliant.- Possibly. } \\
\text { Requirements for overflow on } \\
\text { comb wiring are met. }\end{array}$} & \multicolumn{2}{|c|}{$\begin{array}{l}\text { Mm 3: Percentage } \\
\text { of direct diversion } \\
\text { without treatment } \\
\text { of stormwater from } \\
\text { contaminated } \\
\text { surfaces to sensitive } \\
\text { recipient. }\end{array}$} & $\begin{array}{l}\text { Mm 4: } \\
\text { Flooding/emergency } \\
\text { diversion that affects } \\
\text { lakes, watercourses or } \\
\text { coastal areas that the } \\
\text { authorities have classified } \\
\text { as eutrophication. }\end{array}$ & $\begin{array}{l}\text { Mm } \\
\text { dive } \\
\text { own } \\
\text { sour }\end{array}$ & $\begin{array}{l}\text { n5: Flooding/emergency } \\
\text { ersion that affects one's } \\
\text { nor someone else's water } \\
\text { rce }\end{array}$ \\
\hline \multicolumn{8}{|l|}{ Parameter : Water asset- Mv 1-3 } \\
\hline $\begin{array}{l}\text { Mv 1: Is there a regional water } \\
\text { supply plan? }\end{array}$ & \multicolumn{3}{|c|}{$\begin{array}{l}\text { MV 2: Is there an established water protection area } \\
\text { for the municipality's water source }\end{array}$} & \multicolumn{4}{|c|}{$\begin{array}{l}\text { MV 3: The water supply is satisfactory both now and in the long } \\
\text { term, } 20-30 \text { years. }\end{array}$} \\
\hline
\end{tabular}

Figure A2. "Environmental sustainability" pillar, four related parameters, group codes for parameters, and related questions (key figures). 


\begin{tabular}{|c|c|c|c|c|c|c|c|c|c|c|c|c|c|c|}
\hline \multicolumn{15}{|c|}{ Parameter :The status of W and WS facilities - Rs 1-9 } \\
\hline $\begin{array}{l}\text { Rs1: Is there a } \\
\text { multi-year budget } \\
\text { (3-4 years) } \\
\text { established }\end{array}$ & \multicolumn{6}{|c|}{$\begin{array}{l}\text { Rs2: Finns det en tioårig finansiell plan som } \\
\text { visar hur identifierade investerings- och } \\
\text { förnyelsebehov enligt Rs3, Rs8 \& Rs9 } \\
\text { finansieras? }\end{array}$} & \multicolumn{4}{|c|}{$\begin{array}{l}\text { Rs 3: Is there a plan for renewal-needs pipeline } \\
\text { networks in } 10 \text { years or longer linked to both the } \\
\text { facilities' status and challenges in the form of } \\
\text { climate adaptation. } \mathrm{mm}\end{array}$} & \multicolumn{3}{|c|}{$\begin{array}{l}\text { Rs 4: Status of the water } \\
\text { supply network measured } \\
\text { as calculated leakage (m3 / } \\
\mathrm{km} \text {, day). }\end{array}$} & \\
\hline \multicolumn{5}{|c|}{\begin{tabular}{|l|l|} 
Rs 6:What is the status of the sewer & Rs 7: Renovation \\
network? Answer the question based & of sewer line 5 \\
on TV inspections, stops, flushing & years on \\
needs, \& pipeline's collapses. & average. \\
\multicolumn{2}{|l|}{ Parameter: Stability of operating - Rd 1-3 } \\
\end{tabular}} & \multicolumn{5}{|c|}{$\begin{array}{l}\text { Rs 8:What is the investment/reinvestment need for } \\
\text { WTP and Pumpstations? Make a general assessment } \\
\text { for all facilities based on periodic inspections, risk } \\
\text { assessment, maintenance plans and operational } \\
\text { disruptions/emergencv repairs. }\end{array}$} & \multicolumn{5}{|c|}{$\begin{array}{l}\text { Rs 9: What is the investment/reinvestment need for WWTP } \\
\text { and pumping stations? Make a general assessment for all } \\
\text { facilities based on periodic inspections, risk assessment, } \\
\text { maintenance plans and operational disruptions/emergency } \\
\text { repairs }\end{array}$} \\
\hline \multicolumn{6}{|c|}{$\begin{array}{l}\text { Rd1: Do all pumping stations that overflow/distress lead to b } \\
\text { source or sensitive recipient operating instructions, alarms an } \\
\text { Parameter :Staff resources and competence- Rk 1-22 } \\
\end{array}$} & ing wa & $\begin{array}{l}\text { ater, water } \\
\text { le power? }\end{array}$ & \multicolumn{4}{|c|}{$\begin{array}{l}\text { Rd 2: Are there incident preparedness, both to } \\
\text { handle (prioritize) and remedy crises? }\end{array}$} & \multicolumn{3}{|c|}{$\begin{array}{l}\text { Rd 3:Tränas kris organisationen } \\
\text { regelbundet? }\end{array}$} \\
\hline $\begin{array}{l}\text { Rk1: Are there staff } \\
\text { who take care of } \\
\text { documenting operationa } \\
\text { disruptions and } \\
\text { complaints? } \\
\end{array}$ & \multicolumn{3}{|c|}{$\begin{array}{l}\text { Rk 2: Are there staff who } \\
\text { continuously take care } \\
\text { of the financial follow- } \\
\text { up? }\end{array}$} & \multicolumn{4}{|c|}{$\begin{array}{l}\text { Rk 23: Are there resources } \\
\text { to manage financial } \\
\text { planning and produce the } \\
\text { necessary financial } \\
\text { analvsis? }\end{array}$} & $\begin{array}{l}\text { Rk 3: A } \\
\text { (intern } \\
\text { can rer } \\
\text { disturb }\end{array}$ & \begin{tabular}{l|l} 
rces & RK \\
that & lint \\
nal & can
\end{tabular} & \multicolumn{3}{|c|}{$\begin{array}{l}\text { RK4: Are there resources } \\
\text { (internal or external) that } \\
\text { can fix malfunctions? }\end{array}$} & \multicolumn{2}{|c|}{$\begin{array}{l}\text { Rk5: Are there staff who can } \\
\text { handle the long-term planning? } \\
\text { Look further under the info } \\
\text { button to see what is meant }\end{array}$} \\
\hline \multicolumn{2}{|c|}{$\begin{array}{l}\text { Rk6: Is there electrical } \\
\text { competence (internal or } \\
\text { external), even during } \\
\text { holiday periods/standby? } \\
\text { NOTE resources and skills! } \\
\end{array}$} & \multicolumn{4}{|c|}{$\begin{array}{l}\text { Rk 7: Is there control and } \\
\text { regulatory competence (internal } \\
\text { or external), even during holiday } \\
\text { periods/ standby? NOTE } \\
\text { resources and skills! }\end{array}$} & \multicolumn{3}{|c|}{$\begin{array}{l}\text { Rk8: Is there internal } \\
\text { competence in process } \\
\text { technology water, even during } \\
\text { holiday periods/ preparedness? } \\
\text { NOTE resources and skills! } \\
\end{array}$} & \multicolumn{4}{|c|}{$\begin{array}{l}\text { Rk9: Are there internal competence } \\
\text { process technology drains, even } \\
\text { during holiday periods/emergency } \\
\text { preparedness? NOTE resources and } \\
\text { skills? }\end{array}$} & \multicolumn{2}{|c|}{$\begin{array}{l}\text { Rk10: Is there W \&WS technical } \\
\text { competence for investigation and } \\
\text { design? Internal or external } \\
\text { combined with strong internal } \\
\text { customer functions. NOTE! }\end{array}$} \\
\hline \multicolumn{2}{|c|}{$\begin{array}{l}\text { RK11: Is there internal } \\
\text { process technical competence } \\
\text { for investigation and design? } \\
\text { NOTE resources and skills! }\end{array}$} & \multicolumn{8}{|c|}{$\begin{array}{l}\text { Rk12: Can you handle procurement according to LUF / LOU? Including } \\
\text { preparation of technical specification, documents and evaluation model } \\
\text { through an established and well-functioning collaboration with the } \\
\text { procurement unit/procurement manager (internal/municipal internal)? LUf = } \\
\text { The Act on Procurement in the Utilities Sector. LOU = The Public Procurement }\end{array}$} & & $\begin{array}{l}\text { re a } \\
\text { lager who } \\
\text { a strong }\end{array}$ & \multicolumn{2}{|c|}{$\begin{array}{l}\text { Rk14: is there } \\
\text { capacity to review } \\
\text { received drawings } \\
\text { and other } \\
\text { construction? }\end{array}$} & \\
\hline \multicolumn{2}{|c|}{$\begin{array}{l}\text { Rk16: Are there staff who can } \\
\text { manage the map database? This } \\
\text { work includes having a routine } \\
\text { for drawing up as- built drawings } \\
\text { that are entered into the } \\
\text { database. }\end{array}$} & \multicolumn{2}{|c|}{$\begin{array}{l}\text { Rk17: Company } \\
\text { staff- } \\
\text { experience in } \\
\text { person-years per } \\
\text { employee. }\end{array}$} & \multicolumn{2}{|c|}{$\begin{array}{l}\text { Rk18: is there } \\
\text { plan for } \\
\text { competence } \\
\text { development }\end{array}$} & re a & \multicolumn{2}{|c|}{$\begin{array}{l}\text { Rk19: Do newly hired } \\
\text { operations technicians } \\
\text { complete the current } \\
\text { diploma course within } 4 \\
\text { years? }\end{array}$} & $\begin{array}{l}\text { Rk 20: Are } \\
\text { there key staff } \\
\text { groups that } \\
\text { are difficult to } \\
\text { recruit? }\end{array}$ & \multicolumn{3}{|c|}{$\begin{array}{l}\text { RK21: Will the answers } \\
\text { to questions Rk1-Rk19 } \\
\text { be affected by } \\
\text { impending retirements } \\
\text { in the next few years? }\end{array}$} & \multicolumn{2}{|c|}{$\begin{array}{l}\text { Rk22: Does the } \\
\text { Committee/board set } \\
\text { requirements for documentation } \\
\text { in the form of key figures, long- } \\
\text { term planning and other } \\
\text { compilations that you can } \\
\text { deliver? }\end{array}$} \\
\hline
\end{tabular}

Figure A3. "Sustainable resources” pillar, three related parameters, group codes for parameters, and related questions (key figures).

\section{References}

1. Lidström, V. Vårt Vatten: Grundläggande Lärobok i Vatten-och Avloppsteknik; Svenskt Vatten: Solna, Sweden, 2013. (In Swedish)

2. Bonde, I.; Kuylenstierna, J.; Bäckstrand, K.; Eckerberg, K. Klimatpolitiska Rådets Rapport 2019; Swedish Climate Policy Council: Stockholm, Sweden, 2019. (In Swedish)

3. Svenskt Vatten. Investeringsbehov och Framtida Kostnader för Kommunalt Vatten och Avlopp—En Analys av Investeringsbehov 2020-2040. Available online: https:/ / www.svensktvatten.se/globalassets / rapporter-och-publikationer/investeringsrapporten/ svenskt_vatten_investeringsrapport_202010.pdf (accessed on 9 May 2021). (In Swedish).

4. Malm, A.; Horstmark, A.; Jansson, E.; Larsson, G.; Meyer, A.; Uusijärvi, J. Handbok i Förnyelseplanering av VA Ledningar; Svenskt Vatten AB: Stockholm, Sweden, 2011; p. 122.

5. Jonsson, R.; Syssner, J. Demografianpassad infrastruktur?: Om hantering av anläggnings-tillgångar i kommuner med minskande befolkningsunderlag. Nord. Adm. Tidsskr. 2016, 93, 45-64.

6. Jonsson, R. Organisering och Styrning av Kommunal VA-Verksamhet: En Studie av Förmågor, Brister och Förbättringspotential; Svenskt Vatten AB: Bromma, Sweden, 2017. (In Swedish)

7. Svenskt Vatten. Resultatrapport för Hållbarhetsindex 2019. Available online: https://www.svensktvatten.se/globalassets/ organisation-och-juridik/vass/hallbarhetsindex/hbi_2019_vs200227.pdf (accessed on 9 May 2021).

8. Svenskt Vatten. Hållbarhetsindex för kommunernas VA-verksamhet-Beskrivning av Verktygets syfte och Konstruktion inför Undersökningen. 2017. Available online: https://www.svensktvatten.se/globalassets/organisation-och-juridik/vass/ hallbarhetsindex/hallbarhetsindex_beskrivning-av-verktyget-2017.pdf (accessed on 10 March 2021). (In Swedish).

9. Malm, A.; Svensson, G.; Bondelind, M.; Balmèr, P. Prioriterade Nyckeltal för VA-Verksamheten; Svenskt Vatten AB: Bromma, Sweden, 2018. 
10. Svenskt Vatten. Hållbarhetsindex för Kommunernas VA-Verksamhet, Beskrivning av Verktygets syfte och Konstruktion inför Undersökningen. 2015. Available online: https://www.svensktvatten.se/globalassets/organisation-och-juridik/vass/ hallbarhetsindex/hallbarhetsindex_beskrivning_augusti-2015.pdf (accessed on 15 February 2021). (In Swedish)

11. Erlingsson, G.Ó.; Wänström, J. Politik och Förvaltning i Svenska Kommuner; Studentlitteratur AB: Lund, Sweden, 2015 ; p. 240.

12. Thomasson, A. Organisering för ökad Uthzållighet_En Studie av Olika Organisations Formar Inom den Svenska VA-Sektorn; Svenskt Vatten AB: Bromma, Sweden, 2013.

13. Statskontoret. Det Kommunala Utjämningssystemet-En Beskrivning av Systemet från 2014; Statskontoret: Stockholm, Sweden, 2014.

14. Jonsson, R.; Syssner, J. New demography, old infrastructure: The management of fixed assets in shrinking municipalities in Sweden. In Dealing with Urban and Rural Shrinkage: Formal and Informal Strategies; Hospers, G.J., Syssner, J., Eds.; LIT Verlag: Münster, Cermany, 2017; pp. 31-44.

15. Hopper, A.M. Continuous Improvement Strategies: How to Manage, Motivate, and Retain Staff; CRC Press: Boca Raton, FL, USA, 2018.

16. Parker, S. Measuring up: Size is no obstacle to benchmarking for competitive advantage. Rochester Bus. J. $1992,8,15$.

17. TABAKOVA, V. Is Benchmarking an Effective Tool for Improvement in Project Management? Available online: https:// www.google.com.hk/url?sa=t\&rct=j\&q=\&esrc=s\&source=web\&cd=\&cad=rja\&uact=8\&ved=2ahUKEwjK0NbC_srxAhWLP5 QKHUIUBxUQFnoECAMQAw\&url=https\%3A\%2F\%2Fwww.diva-portal.org\%2Fsmash\%2Fget $\% 2$ Fdiva2\%3A815196\% 2FFULLTEXT01.pdf\&usg=AOvVaw1WiWtItAlTfuZgewo7aGc5 (accessed on 9 April 2021).

18. Mollaee, R.R.S.T.N.; Rahimi, R.; Tavassoli, S. Conforming benchmarking to project management. In Proceedings of the 5th International Conference on Innovation and Management, Maastricht, The Netherlands, 10-11 December 2008.

19. Carlsson, H.; Haraldsson, M.; Kärrman, E.; Lidström, V.; Lundh, M.; Malm, A.; Malmström, H.; Leslie, P.; Ronnbäck, M.; Sjögren, L.; et al. Investeringsbehov och Framtida Kostnader för Kommunalt Vatten och Avlopp; Svenskt Vatten AB: Bromma, Sweden, 2017.

20. Najar, N.; Persson, K.M. Strategies, Processes, and Results for the Future Water Supply of the Växjö Municipality: Evaluation of an Evidence-Based Case Study of Long-Term Strategies within the Water and Wastewater Sector in Sweden. Water 2019, 11, 2150. [CrossRef]

21. Glaas, E.; Hjerpe, M.; Jonsson, R. Conditions Influencing Municipal Strategy-Making for Sustainable Urban Water Management: Assessment of Three Swedish Municipalities. Water 2018, 10, 1102. [CrossRef]

22. Pahl-Wostl, C. An evolutionary perspective on water governance: From understanding to transformation. Water Resour. Manag. 2017, 31, 2917-2932. [CrossRef]

23. Mistra InfraMaint. Mistra InfraMaint Is a Research Programme with the Vision of a Sustainable Infrastructure That Is Available and Safe around the Clock. Available online: https:/ / mistrainframaint.se/ (accessed on 9 May 2021).

24. Malmer, S. Ett Pris Blir Till. Om Förklaringar till Kommunala Avgifter och Taxor. Ph.D. Thesis, Göteborgs Universitet, Gothenburg, Sweden, 23 May 2003.

25. Haraldsson, M.; Tagesson, T. Compromise and Avoidance: The Response to New Legislation. J. Account. Organ. Chang. 2014, 10, 288-313. [CrossRef]

26. Bashir, A.; Mohamud, A. Investeringsfond inom Vatten och Avlopp En studie om avsättning av investeringsfond inom Vatten och Avlopp verksamhet hos utvalda VA-huvudmän. Ph.D. Thesis, School of Business, Economics and Law, University of Gothenburg, Gothenburg, Sweden, 2021. 